\title{
WYBRANE WIADOMOŚCI Z ETNOBOTANIKI I ETNOFARMACJI. KARTY Z DZIEJÓW LECZNICTWA NATURALNEGO
}

\author{
KATARZYNA WOJAN \\ Uniwersytet Gdański \\ Wydział Filologiczny \\ Instytut Skandynawistyki \\ Pracownia Języka Fińskiego, Kultury i Gospodarki Finlandii \\ Neofilologia, ul. Wita Stwosza 51, 80-308 Gdańsk, Polska \\ e-mail: finkw@univ.gda.pl \\ (nadesłano 6.08.2017; zaakceptowano 20.10.2017)
}

\section{Abstract \\ Selected issues from ethnobotany and ethno-pharmacy. Pages from the history of natural medicine}

The article presents a brief history of natural medicine based on substances derived from plants, practiced in the world from the earliest days up until the era of presentday chemistry-based pharmaceuticals. The unusual properties of phytotherapy applied from the ancient times in various cultural and civilizational communities have been shown. The author describes the means available to the ancients, as well as the experiments and discoveries made by scholars of later ages. Attention was paid to the observations important for the development of medicine, medical anthropology and ethnobotany.

\section{Key words}

Cultural anthropology, ethnology, ethnobotany, ethno-pharmacy, history of medicine, medical anthropology, natural medicines, phytonymy. 


\section{Abstrakt}

Artykuł przedstawia krótką historię lecznictwa za pomocą substancji naturalnych pozyskiwanych $\mathrm{z}$ roślin, praktykowanego $\mathrm{w}$ świecie od czasów najdawniejszych po erę dzisiejszych środków farmaceutycznych opartych na chemii. Ukazano w nim niezwykłe właściwości fitoterapii stosowanej od starożytności przez rozmaite społeczności kulturowo-cywilizacyjne. Opisano środki, jakimi dysponowali starożytni, a także jakich doświadczeń i odkryć dokonali uczeni późniejszych epok. Zwrócono uwagę na to, jakie obserwacje poczynione wieki temu okazały się ważne dla dalszego rozwoju medycyny, antropologii medycznej, etnobotaniki.

\section{Słowa kluczowe}

Antropologia kulturowa, etnokultura, etnologia, etnobotanika, etnofarmakologia, fitonimika, historia medycyny, leki naturalne.

Drogiej Pani Profesor Krystynie Szcześniak, Wielkiej Miłośniczce cudownego, mistycznego świata roślin artykuł ten dedykuje

\section{Kilka słów wstępu}

„Rośliny towarzyszyły człowiekowi od zawsze” - napisała w swej znakomitej monografii o pięknym, wymownym tytule: Świat roślin światem ludzi na pograniczu wschodniej i zachodniej Stowiańszczyzny (Gdańsk 2008) ${ }^{2}$ Profesor Krystyna Szcześniak, znana i ceniona badaczka różnych obszarów onomastyki, m.in. botanicznej, oraz etnografii wschodnio- i zachodniosłowiańskiej, w szczególności zamów, tradycji kulturowych, obyczajów obecnych w etnokulturach, symboliki roślin.

Niniejszy artykuł z ogromną przyjemnością i nieskrywaną atencją dedykuję Autorce powyższego motta - Pani Profesor Krystynie Szcześniak, Wielkiej Miłośniczce niezwykłego świata roślin, świadomej wspaniałości darów Natury, Wielkiej Humanistce, dostrzegającej dobro i piękno w drugim człowieku, Wyjątkowemu i Charyzmatycznemu Nauczycielowi, będącemu dobrym duchem młodych pokoleń - studentów, doktorantów, naukowców. Zdaję sobie oczywiście sprawę, iż Pani Profesor posiada rozległą wiedzę etnograficzną na temat flory, historii badań świata roślinnego ${ }^{3}$, ziołolecznictwa

\footnotetext{
1 K. Szcześniak. Świat roślin światem ludzi na pograniczu wschodniej i zachodniej Słowiańszczyzny. Gdańsk: Wydawnictwo Uniwersytetu Gdańskiego, 2008, s. 9.

2 Praca doczekała się drugiego, poprawionego i zaktualizowanego, wydania w roku 2013. Dodam, iż koszty wydawnicze drugiego nakładu poniosła sama Autorka.

3 Zob. rozdział: Historia badań świata roślinnego. [W:] K. Szcześniak. Świat roślin światem ludzi..., s. 9-30.
} 
i etnofarmacji. Żywię jednak nieśmiało nadzieję, że pewne wiadomości zebrane i usystematyzowane przeze mnie okażą się w jakiejś mierze nowe i ciekawe.

Celem niniejszej pracy jest przedstawienie krótkiej historii lecznictwa za pomocą substancji naturalnych, zwłaszcza zaś tych pozyskiwanych z roślin, praktykowanego na świecie od czasów najdawniejszych po erę dzisiejszych środków farmaceutycznych opartych na chemii i biotechnologii, a także pokazanie niezwykłych właściwości fitoterapii stosowanej od starożytnych czasów przez rozmaite społeczności kulturowo-cywilizacyjne. Poniższe rozważania przybliżają, bądź też przypominają, wiedzę na temat kształtowania się metod i form praktyk leczniczych dokonywanych na przestrzeni tysiącleci. Syntetyczne ujęcie wiadomości na temat lecznictwa naturalnego ukazuje ukierunkowanie ludzkiego myślenia na to, jak świadomie chronić życie i zdrowie oraz jak przynieść ulgę w cierpieniu. Artykuł informuje, jakimi środkami dysponowali starożytni, a także jakich doświadczeń i odkryć dokonali uczeni późniejszych epok. Uzmysławia on, jakie poczynione wieki temu obserwacje okazały się ważne dla rozwoju medycyny, antropologii medycznej, etnobotaniki. Na koniec zwrócono uwagę i krótko przedstawiono szkodliwe działanie pewnych związków zawartych w roślinach.

Zaprezentowane tu wiadomości zgromadzone zostały na podstawie dostępnego piśmiennictwa - serii artykułów specjalistycznych oraz opracowań monograficznych dotyczących historii etnomedycyny i właściwości fitoterapeutycznych roślin ${ }^{4}$. Szkic ma charakter humanocentryczny. Zamieszczono w nim jedynie ważniejsze fakty z historii etnofarmakologii i etnomedycyny - temat ten bowiem nie jest i nie może być, rzecz jasna, wyczerpany. Artykuł ma charakter przeglądowy.

Rozwój lecznictwa ma niezwykle długą historię. Kształtowało się ono na przestrzeni wielu tysiącleci ${ }^{5}$. Jak pisze Władysław Szumowski ${ }^{6}$, „Już w świecie zwierzęcym spotykamy pewne zabiegi mające pewne znaczenie lecznicze”. Najpierw zwierzęta, a w ślad za nimi, ludzie uczyli się instynktownie korzystać z bogactwa darów natury potężnego arsenału specyfików naturalnych, które dziś nazywamy lekami. W historii ludzkości podejście zarówno do samej choroby, jak i do sposobów jej leczenia ${ }^{7}$, a także, co istotne, stosunku do chorego zmieniało się. Praktykowano różne metody

4 Alfabetyczny spis pozycji bibliograficznych literatury przedmiotu, z jakiej obficie korzystałam, zamieszczam na końcu pracy. Literatura nt. historii lecznictwa jest nader obszerna. Do ważniejszych opracowań monograficznych należą: sześciotomowa Historia leków naturalnych pod red. B. Kuźnickiej, Historia medycyny W. Szumowskiego. Odwołania do poszczególnych prac zawarłam w przypisach.

5 Zob. np. Historia leków naturalnych. T. 2: Natura i kultura. Współzależności w dziejach lekoznawstwa. Red. B. Kuźnicka. Warszawa: Wydawnictwo Instytutu Historii Nauki, Oświaty i Techniki, 1989. 6 W. Szumowski. Historia medycyny filozoficznie ujęta. Wyd. 4 popr. i uzup. Kęty: Wydawnictwo Marek Derewiecki, 2008, s. 27.

7 Słowa lek oraz leczyć są, jak wiadomo, bardzo stare, ujawniają praindoeuropejski rdzeń (por. st.niem. lahhi 'leczyć', st.ang. loece, st.nordyckie loeknir, gockie lēkeis, śr.niem. i śr.niderlandzkie lieke, śr.ang. leche). W językach indoeuropejskich formalno-semantyczne ekwiwalenty przekładowe słowa leczyć miały pierwotnie zakodowany sens: 'wyciągnąć chorobę z chorego organizmu'. W takim znaczeniu funkcjonowało ono jeszcze w XVI-wiecznej polszczyźnie (np. w Herbarzu Marcina Siennika z 1568 roku). Za: Z. Bela Etymologia i pierwotne znaczenia wyrazów »lek« $i » l e c z y c ́$ «. „Gazeta Farmaceutyczna", marzec 2011, s. 16-28. 
mające na celu przynieść ulgę cierpiącemu, poratować lub zachować zdrowie czy też urodę. Podstawy naukowe teorii i praktyki medycznej wypracowano dopiero przed dwustu laty. Do obecnego stanu wiedzy ludzie dochodzili stopniowo. Często wielkie odkrycia przeplatały się z przesądami - w nierozerwalnym związku pozostawały czary i lecznictwo, kapłaństwo i medycyna ${ }^{8}$. W zamierzchłych czasach, na długo przed pojawieniem się piśmiennictwa, w charakterze leków wykorzystywano rośliny, minerały (skały i kopaliny), części organizmów żywych, a także miód i wody mineralne? W starożytności korzystano już z aromaterapii i balneologii, kładziono nacisk na higienę i profilaktykę zdrowia, dbano o kosmetykę ciała i kondycję psychiczną. Niektóre popularne smakowite napoje, na przykład coca-cola ${ }^{10} \mathrm{czy}$ tonik, dawniej traktowane jako lek, są wymysłem aptekarzy. W XIX wieku Vincenz Priessnitz, niewykształcony chłop pochodzący ze Śląska Austriackiego, ojciec współczesnego wodolecznictwa, głosił, że myśl o stosowaniu wody w celach leczniczych nasunęła mu sarna mocząca w strumyku postrzeloną nogę do zagojenia się rany ${ }^{11}$. W medycynie prymitywnej przyczyn zachorowań doszukiwano się w magii ${ }^{12}$. Leczenie było domeną szamanów uzdrawiających przy pomocy różnego rodzaju rytuałów, amuletów, roślin, organizmów zwierzęcych ${ }^{13}$. W ziołolecznictwie niełatwo było rozdzielić magię od rzetelnej wiedzy przynoszącej właściwą korzyśćc ${ }^{14}$. W Europie ludzie aż do połowy XIX wieku posługiwali się wyłącznie lekami roślinnymi ${ }^{15}$. Wiele ziół do dnia dzisiejszego okrywa wciąż nimb tajemnicy. Człowiek, tak jak i inne zwierzęta ${ }^{16}$, w okresach swej niemocy wybierał rośliny, kierując się instynktem. Wybierał intuicyjnie te spośród nich, które łagodziły jego cierpienia, a ponadto uzdrawiały. Człowiek jako istota rozumna, żyjąc i poznając otaczający go świat, niestrudzenie czynił obserwacje - przede wszystkim obserwował różne zjawiska i poznawał to, co ofiarowała mu Matka-Natura ${ }^{17}$. Człowiek jest przecież istotą cierpiącą. Z czasem nauczył się rozpoznawać, które rośliny posiadają jakąś moc, które uśmierzają jego ból, które przywracają siły i zdrowie, a które

8 Na ten temat zob. W. Szumowski. Historia medycyny filozoficznie ujęta..., s. 33-90.

9 R. Jütte. Historia medycyny alternatywnej. Od magii do naturalnych metod leczenia. Tł. K. Jachimczak, E. Ptaszyńska-Sadowska. Warszawa: Wydawnictwo WAB, 2001.

10 Oryginalny skład zawierał wyciągi z orzeszków cola i liści coca, zawierające silne stymulanty (kofeinę i kokainę) - S. Kucharski. Coca-colę wynalazł aptekarz. „Bez Recepty”, maj 2003.

11 W. Szumowski. Historia medycyny..., s. 28.

12 R. Jütte. Historia medycyny alternatywnej...

13 Zob. W. Szczepański. Leki pochodzenia zwierzęcego w farmakopeach polskich od 1560 do 1970. [W:] Historia leków naturalnych. Cz. 2: Natura i kultura - współzależności w dziejach lekoznawstwa. Red. B. Kuźnicka. Warszawa: Wydawnictwo Instytutu Historii Nauki, Oświaty i Techniki, 1989.

14 K. Hanisz. Ziołolecznictwo w medycynie ludowej. Cz. II: Fitoterapia magiczna. „Bez Recepty” 2002, nr 10, s. 24-25.

15 K. Hanisz. Ziołolecznictwo w medycynie ludowej. Cz. I. „Bez Recepty” 2002, nr 9, s. 24-25; K. Hanisz. Apteczki w polskich dworach i dworkach - historia farmacji. „Bez Recepty” 2001.

$16 \mathrm{~Np}$. kozica, ukąszona przez żmiję, instynktownie zjada wilczomlecze. Zob. Zielnik dla każdego, czyli opis ziót wykorzystywanych $w$ leczeniu domowym wraz z praktycznym zastosowaniem. Zebrał i oprac. J. Rogala oraz R. Maciej. Ożarów: Wydawnictwo Olesiejuk, 2009, s. 5.

17 Indianie, na przykład, zaobserwowali, że chore na malarię pumy obgryzają korę drzewa chininowego. 
po prostu polepszają nastrój. Jednocześnie poznawał swoje reakcje na poszczególne substancje zawarte $\mathrm{w}$ roślinach. Odkrywał rośliny, które mają silniejsze działanie fizjologiczne - przeczyszczające, wymiotne, moczopędne, mlekopędne, powstrzymujące krwawienia, przeciwgorączkowe, aseptyczne, odurzające, przeciwbólowe. Nauczył się ich używać w chorobach i dolegliwościach, a zatem uznał je za leki, czyli coś, co przynosi ulgę i poprawia nastrój, ratuje ${ }^{18}$. $Z$ czasem posiadł szerszą wiedzę o roślinach i ich właściwościach pokarmowych, paszowych, leczniczych, trujących, którą następnie spisał w znany mu sposób. Ludzie zaczęli wykorzystywać zioła nie tylko w celach leczniczych, lecz także w kuchni, jako barwniki i kosmetyki. Do najwcześniej używanych ziół należały mak, mandragora, konopie, lulek czarny i dzbanecznik ${ }^{19}$. Dla farmaceutów rośliny stanowią ważny surowiec leków o różnym spektrum działania. Paracelsus - bazylejski profesor sztuki lekarskiej - nie bez powodu nazwał pola, łąki i lasy „prawdziwymi aptekami”20, z których można czerpać nieskończenie.

O wielkich wartościach ziół wiedziano już w czasach prehistorycznych. Stosować je jednak zaczęto znacznie później. Nie dziwi to, bowiem człowiek musiał najpierw poznać świat roślin, odkryć ich magię, wartości, „wypróbować” i nauczyć się z nich korzystać. Ziołolecznictwo ${ }^{21}$ rozpowszechnione było, i jest nadal, we wszystkich znanych nam cywilizacjach świata (także Indian ${ }^{22}$ amerykańskich, aborygenów australijskich) ${ }^{23}$. Jest to najprostszy, naturalny, a zarazem tani sposób pozyskiwania leków, leczenia różnorakich schorzeń i dolegliwości. Na dowolnym obszarze kuli ziemskiej występuje swoista roślinność (endemity). Indianie czy aborygeni australijscy dysponowali dużo większym inwentarzem ziół, i to znacznie wcześniej niż medycy greccy czy rzymscy. Wraz z odkryciem Ameryki wiedzę o roślinach i nowych medykamentach $\mathrm{z}$ nich pozyskiwanych rozpropagowano $\mathrm{w}$ europejskim świecie medycznym ${ }^{24}$. Właśnie z Ameryki przywieziono na stary kontynent m.in. korę chinowca (Cinchona L.) ${ }^{25}$ mającego zastosowanie w zwalczaniu malarii dzięki zawartości chininy, balsam peruwiański (Balsamum peruvianum) - wyciekający z uszkodzonej kory woniawca balsamowego (Myroxylon balsamum) i stosowany przy różnorodnych dolegliwościach, liście coca - z krasnodrzewu pospolitego (Erythroxylum coca) - bogate w kokainę

18 O tym: J. Dobrogowski et al. Ból i jego leczenie. Seria Przewodnik Lekarza Praktyka. Warszawa: Springer PWN, 1996.

19 M. Hilgier. Historia i leczenie bólu przewlekłego. „Nowa Medycyna” 2001, z. 2 (110).

20 Zielnik dla każdego..., s. 6.

21 J. Thorwald. Dawna medycyna, jej tajemnice i potega. Egipt, Babilonia, Indie, Chiny, Meksyk, Peru. Przeł. A. Bandurski i J. Sczaniecka Wrocław: Zakład Narodowy im. Ossolińskich - Wydawnictwo, 1990.

22 Por. J.Z. Ryn. Medycyna indiańska. Kraków: Wydawnictwo Literackie, 2007.

23 Zob. np. Ziołolecznictwo amazońskie i andyjskie. Red. K. Żurowska. Gdańsk: Tower Press, 2001.

24 Zob. W. Jaroniewski, D. Jaroniewska. Rośliny lecznicze i używki z Ameryki i Australii. Łódź: Instytut Wydawniczy Związków Zawodowych, 1996; K. Hanisz, J. Mularczyk. Z historii leków uzależniających. Liście koka i kokaina. „Bez Recepty”, kwiecień 2002.

25 Zob. J. Molenda. Rośliny, które zmieniły świat; fakty i mity na temat właściwości leczniczych warzyw i owoców, anegdoty i zagadki roślinnych peregrynacji, kulisy ewolucji gatunków. Zakrzewo: Replika, 2011. 
i wprowadzające pacjenta w stan snu narkotycznego pożądany przed poważniejszymi zabiegami chirurgicznymi ${ }^{26}$.

Najstarszymi księgami opisującymi lecznicze właściwości roślin są księgi chińskie, indyjskie, papirusy egipskie, wreszcie dzieło ojca medycyny - Hipokratesa. Kultura europejska jest spadkobierczynią kultury grecko-rzymskiej, wzorującej się z kolei na egejskiej i egipskiej, następnie babilońskiej, sumeryjskiej itd. Zdecydowanie mniejszy wpływ na nią wywierały kultury Indii i Chin.

Warto także wspomnieć, iż już w starożytności podejmowano próby zastosowania do walki z chorobami drobnoustrojów lub produktów ich metabolizmu ${ }^{27}$.

\section{Lecznictwo babilońskie i asyryjskie}

W starożytnej Mezopotamii lecznictwo było stosunkowo dobrze rozwinięte ${ }^{28}$. Stosowano magię (wypędzanie duchów z chorego poprzez rytuały) i amulety oraz leczenie roślinami. Systematyczne badania właściwości ziół sięgają czasów starożytnych Sumerów (4000 p.n.e.), którzy sporządzili opisy działania i użycia m.in. kminku (Carum carvi L.), macierzanki tymianu (Thymus vulgaris L.), wawrzynu (Laurus L.); robili $\mathrm{z}$ nich proszki i nalewki, stosowali kompresy i okłady. Sumerowie stosowali w terapii także surowce zwierzęce, na przykład skorupy żółwi, skórę, ciała węży, surowce mineralne, m.in. muł rzeczny, olej skalny i asfalt. Babilończycy i Asyryjczycy znali 250 surowców leczniczych pochodzenia roślinnego, 180 zwierzęcego i 120 mineralnego; posiadali rozległą wiedzę na temat upraw ${ }^{29}$, zbierania, suszenia i przechowywania ziół, która jest aktualna do dziś. Już w VIII wieku p.n.e. opisywano rośliny i sporządzano na glinianych tabliczkach przepisy na korzystanie z nich. Ordynowanie leków współgrać musiało $\mathrm{z}$ datą, porą dnia, a także położeniem gwiazd.

\section{Lecznictwo indyjskie}

Ważnym ośrodkiem zielarskim były Indie, gdzie wiedza medyczna stała na wysokim poziomie. Hindusi wychodzili z założenia, iż na każdą chorobę musi istnieć lekarstwo. Jeden z najsławniejszych hinduskich lekarzy Susruta znał aż 760 leków roślinnych ${ }^{30}$. Europejczycy zawdzięczają Hindusom wiele atrakcyjnych przypraw i substancji leczniczych o wyjątkowych właściwościach, m.in. cynamon (wysuszona kora cynamonowca Cinnamomum Scheffer), korzeń imbiru (imbir lekarski Zingiber officinale Rosc), owoce kminku (lud. karolek) (Carvi fructus), pieprz (Piper L.), kardamon (Elettaria cardamomum L.), znamiona szafranu (Crocus sativus), goździki (nierozkwitłe, wysuszone pąki kwiatowe drzewa goździkowego, czapetki pachnącej Syzygium aromaticum), gałkę muszkatołową (nasiona muszkatałowca Myristica fragrans Houtt.),

\footnotetext{
26 Por. D. Szczygielska. Kokainowiec pospolity. „Wiadomości Zielarskie” 1993, nr 7.

27 S. Russell. Antybiotyki. Warszawa: Państwowe Wydawnictwo Naukowe, 1977, s. 26-27.

28 O tym: W. Szumowski. Historia medycyny...

29 Babiloński król Mardukapaliddina (panujący 721-710 p.n.e.) posiadał ogród z roślinami leczniczymi. Zob. W. Szumowski. Historia medycyny...

30 Pisze o tym W. Szumowski w swojej pracy: Historia medycyny..., s. 59.
} 
osnówkę (epimacjum, arylus, łac. arillus), spikanardę (olejek nardowy, nard, szpinakard) ${ }^{31}$, senes (liście kilku gatunków krzewów z rodzaju Senna Mill.), nasiona głogu (Crataegus L.), olej sandałowy (Santalum album), nasiona rycynowe (rącznika pospolitego Ricinus communis L.), konopie indyjskie (Cannabis indica Lam.). Ze Wschodu na Zachód przywędrowały rośliny dostarczające haszyszu (konopie) ${ }^{32}$, opium ${ }^{33}$, indygo ${ }^{34}$, czarcie łajno (smrodzieniec, asafetyda) ${ }^{35}$, różne gumy, żywica benzoesowa (styraks, bensoes, benzoin) ${ }^{36}$, sok z trzciny cukrowej (Saccharum officinarum L.) itp. Powszechnie używano również środków mineralnych. Hindusi znali już związki rtęci (kalomel, sublimat, cynober), dolegliwości leczyli preparatami z żelaza, znali trujące i lecznicze właściwości arszeniku, związki ołowiu, miedzi, stosowali antymon (wymiotnie). Ze złota przygotowywali eliksir na przedłużenie życia, wykorzystywali w procesie leczenia kamienie szlachetne. Indyjskie przepisy o sporządzaniu lekarstw i ich działaniu przesycone były pierwiastkami teurgii, magii, wiary w siły nadprzyrodzone. Hindusi posiadali również niezwykły inwentarz leczniczych środków zwierzęcych, takich jak krew, żółć, mleko, masło, serwatka, miód, tłuszcz, szpik, mięso, skórę, nasienie, zęby słonia, rogi, kopyta, włosy, kamienie żółciowe wołu, mocz, gnój (krowi w przypadkach zapalenia, a słoniowy - trądu). Środki lecznicze klasyfikowano według ich działania (przeczyszczające, wymiotne, uspokajające, podniecające, pobudzające do kichania itd.), według smaku (słodkie, kwaśne, słone, gorzkie, ostre, ściągające itd.) albo według przypuszczalnego mechanizmu działania (rozgrzewające, chłodzące, wysuszając, rozmiękczające) ${ }^{37}$. Hindusi znali i trucizny, i odtrutki. Szczegółowo opisywali objawy zatrucia truciznami pochodzenia roślinnego, zwierzęcego, mineralnego. Podawali leki pochodzenia naturalnego na przyspieszenie akcji porodowej.

\section{Lecznictwo chińskie}

Początki zielarstwa w Chinach sięgają 4000 lat p.n.e. ${ }^{38}$. W Państwie Środka odnaleziono zapiski na kościach wróżebnych z II wieku p.n.e. o stosowaniu ziół w różnych schorzeniach. Niektóre źródła ${ }^{39}$ podają, iż najstarszy zielnik świata - wielka księga

31 Olejek eteryczny otrzymywany z korzenia i łodygi rośliny Nardostachys jatamansi, rosnącej w Himalajach na wysokości 3000-4000 m n.p.m.

32 Substancja otrzymywana ze zlepionej i sprasowanej żywicy konopi indyjskich (Cannabis sativa indica) lub siewnych (Cannabis sativa sativa), zawierających substancję psychoaktywną tetrahydrokannabinol.

33 Substancja otrzymywana za pomocą wysuszenia soku mlecznego z niedojrzałych makówek maku lekarskiego (Papaver somniferum).

34 Barwnik otrzymywany z liści tropikalnej rośliny indygowca barwierskiego (Indigofera tinctoria L.).

35 Gumożywica otrzymywana z korzeni i kłączy zapaliczki cuchnącej (Ferula assa-foetida), występującej w północnych Indiach, Iranie i Afganistanie.

36 Żywica balsamiczna pozyskiwana z naciętych pni drzew z rodzaju styrak (Styrax), głównie Styrax benzoin i S. tonkinensis, rosnących w Azji Wschodniej i Indiach.

37 Wiadomości zebrane na podstawie: W. Szumowski. Historia medycyny..., s. 60.

38 O tym: W. Szumowski. Historia medycyny...

39 S. Dłużewski. Szen-Nung. Poczet wielkich fitoterapeutów. [Online:] <http://panacea.pl/articles. php?id=60> (dostęp: 16.05.2010). 
Pen-cao (kompendium lekarskie) sporządzona została w 3216 roku p.n.e. przez pierwszego hipotetycznego władcę Chin cesarza Szen-Nung, ogłoszonego ojcem tamtejszego zielarstwa i ogrodnictwa. Bywa on niekiedy nazywany Szen-Nung-Pen-cao (co oznacza 'cesarza zielarza'), ponieważ wprowadził wiele nieznanych wcześniej Chińczykom roślin użytkowych. Wieść głosi, że jako jedyny człowiek zgłębił on całą florę Chin i tajniki właściwości leczniczych roślin. Pen-cao jest traktatem o surowcach leczniczych i sposobach ich zastosowania i zawiera ponad 8000 recept opartych na 1800 surowcach, głównie roślinnych. Zioła pogrupowano - zgodnie z tradycyjnym podziałem chińskim - według trzech klas. Wyróżniono zatem klasę: a) „książęcą”, tj. zioła podtrzymujące życie, nieszkodliwe dla organizmu człowieka, b) „ministerską”, tj. zioła zwalczające ciężkie choroby i przywracające energię, c) „asystencką”, tj. zioła leczące pewne choroby, ale trujące i nienadające się do stałego użytku ${ }^{40}$.

Przyjmuje się, iż pierwsza w świecie farmakopea nosząca tytuł Szen-Nung-pen-cao-tsing powstała w 502 roku n.e. Nawiązuje ona do eksperymentów prowadzonych przez Szen-Nunga i zawiera opisy 730 roślin leczniczych. W Chinach ziołolecznictwo rozwijane było bardzo intensywnie. W XVI wieku znano już i opisano 1892 gatunki roślin mających wartość leczniczą. Do dziś jednym z najsłynniejszych leków chińskich jest korzeń żeń-szenia ('korzeń życia'). Niewątpliwie należy on do najstarszych surowców leczniczych odkrytych przez chińskiego mędrca La Tse około 320 roku p.n.e. Uczeni dowiedli, iż żeń-szeń (ginseng, wszechlek, Panax ginseng C.A. Meyer) pojawił się w Azji przed czterema tysiącami lat. Sprowadzony do Europy w XIV wieku używany był głównie jako afrodyzjak. Chińczykom zawdzięczamy takie odkrycie właściwości leczniczych rzewienia chińskiego (rabarbaru dłoniastego, Rheum palmatum L.), stosowanego przy nieżytach żołądka i jelit, kamforę, ziele przęśli, efedrynę, a także chińską herbatę (Camellia sinensis (L.) Kuntze). Mieszkańcy Chin wierzyli, iż natura kryje w sobie lek na każdą chorobę i dolegliwość, a leczenie naturalne ma ścisły związek z religią. Chińczycy wypróbowali wiele najróżnorodniejszych środków, dochodząc do biegłości empirycznej. Potrafią na przykład leczyć rozwiniętą wściekliznę, na choroby skórne stosują siarkę, ałun, arszenik, rtęć. Kiłę leczą poprzez zakładanie choremu do nosa napełnionej cynobrem (siarczkiem rtęci) tutki papierowej i zapalanie jej, co w efekcie powoduje oddychanie parą $\mathrm{rtęci}^{41}$.

Chińczycy od XI wieku n.e. stosują szczepienia ochronne przeciw ospie ${ }^{42}$. Popularna jest akupunktura stosowana na różne choroby i dolegliwości. Chińskie nazwy leków są niezwykle tajemnicze, na przykład „proszek trzech największych mędrców”, „proszek pięciorakiego pochodzenia”. Recepta składa się z kilku środków, najczęściej przyjmuje się pięć dawek. Przy doborze leków Chińczycy zwracają szczególną uwagę na istniejące w przyrodzie znaki symboliczne (sygnatury), na przykład szafran (Crocus L.) z uwagi na żółtą barwę jest skuteczny żółtaczce, zaś świetliki (robaczki) świętojańskie (Lampyris noctiluca), ponieważ świecą, powinny ich zdaniem wchodzić w skład wody do oczu.

\footnotetext{
40 O tym: W. Szumowski. Historia medycyny...

41 O tym: W. Szumowski. Historia medycyny...

42 Ibidem, s. 70.
} 


\section{Lecznictwo egipskie}

Kolebką wiedzy lekarskiej był niewątpliwie starożytny Egipt, a lekarze egipscy uchodzili za najlepszych w świecie, o czym niejednokrotnie wspominał Herodot. Medycyna starożytnych Egipcjan, podobnie jak medycyna babilońska, miała charakter empiryczno-supranaturalistyczny i sakralny ${ }^{43}$. Medycynę stworzyli bogowie, a największe zasługi $\mathrm{w}$ tej dziedzinie przypisywano Tothowi, o wizerunku z głową ibisa; miał on być twórcą rozmaitych wynalazków, m.in. enemy ${ }^{44}$. Lekarze należeli do kasty kapłanów, której obowiązkiem było uprawianie i przechowywanie rozległej wiedzy w świątyniach.

Nad Nilem zrodziła się nauka o leku - nazwa farmacja wywodzi się ze starożytnego egipskiego ph-ar-maki kto zapewnia bezpieczeństwo ${ }^{35}$. Prawdopodobnie ze staroegipskiego pochodzi też pojęcie chemia ${ }^{46}$ (st.egip. khemein lub khēmia, wg Plutarcha st.egip. kēme 'kraina czarnej ziemi' jako endoetnonim kraju 'Egipt ${ }^{47}$, w hieroglifach: $\mathrm{khm}$ ). Od prawieków uprawiano tam metalurgię, farbiarstwo i alchemię. Arsenał leków egipskich - pochodzących zarówno ze świata roślinnego, jak zwierzęcego i mineralnego - był niezwykle bogaty. Źródłem wiedzy o ówczesnej medycynie są napisy i rysunki na budowlach, egipskie papirusy oraz dzieła Herodota i Pliniusza Starszego. Pierwsze wzmianki na temat leków pojawiają się w zapisach hieroglificznych umieszczonych na posągu boga Thotha - patrona mądrości, lekarza i maga ${ }^{48}$. Najbardziej cennymi w odkrywaniu tajników wiedzy medycznej, jaką posiadali starożytni egipscy uczeni uzdrowiciele, są oczywiście papirusy: z Kahun (2250 r. p n.e.), Smitha (1555 r. p.n.e.), Ebersa (1550 r. p.n.e.), Hearsta (1550 r. p.n.e.), Ermana (1550 r. p.n.e.), berliński (1350 r. p.n.e.), londyński (1350 r. p.n.e.), Chester-Beatty (1200 r. p.n.e.).

Obecność roślin leczniczych odkryto na zwojach mierzącego $20.23 \mathrm{~m}$ papirusu medycznego, znalezionego przez pewnego Araba między nogami mumii odkrytej w Tebach i sprzedanego w 1873 roku lipskiemu egiptologowi, Georgowi Ebersowi. Papirus Ebersa pochodzi z około 1550 roku p.n.e., ale - jak wynika $\mathrm{z}$ analizy tekstów - jego fragmenty są najprawdopodobniej odpisem ze źródeł starszych o 1000 lat. Papirus Ebersa nazwany został przez swoich autorów „księgą o sporządzaniu leków dla wszystkich części ciała ludzkiego"49. Zawiera on opis leków (ok. 500 różnorodnych

43 Ibidem, s. 53.

44 „Z chęci zapobiegania chorobom powstał przepis, że należy trzy dni w każdym miesiącu dzień po dniu brać na wymioty i stosować enemy” - op. cit., W. Szumowski. Historia medycyny..., s. 56.

45 W. Giermaziak. Początki farmacji w cieniu piramid. „Bez Recepty”, styczeń 2009.

46 W. Szumowski. Historia medycyny..., s. 54. Por. hasło: alchemy [w:] The Oxford English Dictionary. Ed. J.A. Simpson and E.S.C. Weiner. Vol. 1, 2nd ed., Oxford: Clarendon Press - New York: Oxford University Press 1989. Zob. też hasło: alchemy (n) [w:] Online Etymology Dictionary. [Online:] <https://www.etymonline.com/word/alchemy> (dostęp: 10.10.2017).

47 Zob. hasło: alchemy [w:] The Oxford English Dictionary. Ed. J.A. Simpson and E.S.C. Weiner. Vol. 1, 2nd ed., Oxford: Clarendon Press - New York: Oxford University Press 1989. Zob. też hasło: alchemy (n) [w:] Online Etymology Dictionary. [Online:] <https://www.etymonline.com/word/alchemy> (dostęp: 10.10.2017).

48 Za: W. Giermaziak. Początki farmacji w cieniu piramid...

49 Ibidem. 
środków leczniczych) i zakresu ich stosowania. Stanowi niezwykle imponujący receptariusz - składa się z 29 części, 100 rozdziałów i notuje około 900 recept. Należy uściślić, iż w skład receptury wchodziły głównie zioła, niekiedy także środki pochodzenia zwierzęcego (w tym leki pszczele) i minerały ${ }^{50}$. W charakterze rozpuszczalników wykorzystywano zaś wino, piwo, oliwę, mleko, wodę, a nawet mocz. Leki, jakie znalazły się w spisach, zalecano na choroby żołądka, na przeczyszczenie (olej rycynowy, zażywany z czymś w rodzaju piwa), wymioty (cebulę morską), guzy zapalne (tj. nowotwory) w przewodzie pokarmowym, tasiemce, glisty, usunięcie plam wątrobowych (tzw. ostudy), pozbycie się potówek, zapalenie odbytu i sromu, obstrukcję, blednicę egipską, bóle głowy, ból dziąseł, skąpomocz, łzawienie oczu, oparzeliny, a nawet wzmocnienie muskułów. Doceniano opium na uśmierzenie bólu, jałowiec (Juniperus L.) jako środek moczopędny, korę granatowca (Punica granatum L.) przeciw robaczycy, bylicę piołun (Artemisia absinthium L.) jako lek zwiększający łaknienie, tatarak (Acorus), miętę pieprzową (Mentha piperita L.), lulek (Hyoscyamus L.), mirrę (wonną żywicę z balsamowca Commiphora), kulczybę wronie oko (Strychnos nux-vomica L.), cynamon (z cynamonowca Cinnamomum), czosnek (Allium sativum L.), cebulę (Allium cepa L.), kmin (karolek, Carum carvi L.), mak polny (Papaveraceae Juss.), sałatę (Lactuca L.), siemię lniane (nasiona lnu zwyczajnego, Linum usitatissimum L.), różę (Rosa L.), szafran (Crocus L.), daktyle (owoce daktylowca właściwego Phoenix dactylifera), mandragorę (Mandragora officinarum L.), lotos (Nelumbo Adans), aloes (Aloë L.) i in. ${ }^{51}$ Co ciekawe, w receptariuszach występuję bardzo poetyckie nazwy roślinnych środków leczniczych, na przykład bylicę piołun (Artemisia absinthium L.) określano jako „serce sępa”, a werbenę (witułkę, Verbena L.) - „łzy ibisa”52. Warto zamieścić tu następującą ciekawostkę - w lekospisie utrwalonym na papirusie Ebersa zawarty jest przepis na lek, który miał sporządzać dla siebie największy egipski lekarz i farmaceuta - Re, bóg Słońca. Preparat ten składa się m.in. z kminku, miodu i wosku ${ }^{53}$.

Innym ważnym dokumentem medycznym jest papirus Smitha znaleziony w 1862 roku w grobowcu w pobliżu Teb przez Edwina Smitha, pochodzący z 1555 roku p.n.e., zawierający odpisy dużo wcześniejszych informacji dotyczących charakterystyk (48) chorób wewnętrznych, chirurgii, metod nastawiania i unieruchamiania złamanych kończyn, leczenia infekcji i gorączki, uszkodzeń neurologicznych. Papirus zawiera także dane na temat poczynionych obserwacji anatomicznych (wzmianki o akcji serca, obliczeniach tętna). Powszechnie uważa się jednak, iż autorem tego „traktatu chirurgicznego" jest sam Imhotep ${ }^{54}$ - żyjący ok. 2900 roku p.n.e. pierwszy lekarz znany z imienia ze źródeł historycznych, twórca egipskiej medycyny, autor ksiąg medycznych, deifikowany urzędnik faraona Dżesera, bóg-uzdrowiciel, mędrzec, uprawiający magię. Uczeni przypuszczają, iż to właśnie Imhotep był autorem etyki zawartej w tzw. przysiędze Hipokratesa.

$\begin{array}{ll}50 & \text { Ibidem. } \\ 51 & \text { Ibidem. } \\ 52 & \text { Zielnik dla każdego..., s. 6-7. } \\ 53 & \text { M. Kora. Zielona medycyna. Apiterapia, homeopatia, ziołolecznictwo. Przewodnik pacjenta. }\end{array}$ Wyd. 2 uzup. Warszawa: Oficyna Wydawnicza Eko-Vital, 1996, s. 19.

54 J. Baines, J. Málek. Wielkie kultury świata. Egipt. Przeł. z ang. T. Derda. Warszawa: Penta, 1995. 
Kolejnym źródłem historii farmacji jest tzw. papirus Hearsta z 1550 roku p.n.e. stanowiący odpisy z ksiąg świętych. Zawiera on szczegółowe instrukcje sporządzania leków oraz opisy konkretnych przypadków ich użycia. Z kolei 80 recept zamieszczono w tzw. papirusie berlińskim, odnalezionym w Sakkarze przez Heinricha Brugscha, a pochodzącym z 1350 roku p.n.e. Księgą recept jest także papirus londyński z tego samego okresu ${ }^{55}$.

Starożytni uzdrowiciele egipscy dużą wagę przywiązywali także do profilaktyki chorób $^{56}$, zachęcając przede wszystkim do higienicznego trybu życia. Potrafili oni racjonalnie leczyć i zapobiegać, znali właściwości odkażające kadzidła o nazwie kyphi (wierzyli również, że odstrasza ono choroby) ${ }^{57}$. Współcześnie wiadomo, że podczas jego spalania wydziela się kwas karbolowy bądź fenol, które są silnymi środkami bakteriobójczymi. Egipska wiedza medyczna była niezwykle ceniona przez współczesnych okresie, a lekarze-uzdrowiciele znad Nilu uchodzili za znakomitych praktyków. Lekarze-kapłani uzdrawiający swych pacjentów także przy pomocy magii ${ }^{58}$ i zaklęć, pełnili rolę ówczesnych psychoterapeutów. W Egipcie istniał podział na poszczególne specjalizacje $^{59}$. Lekarze byli doskonale zorganizowani ${ }^{60}$ i opłacani przez państwo. Istniał też dobrze rozwinięty system ich kształcenia. W dużych miastach działały liczne przyświątynne instytucje - tzw. Domy Życia, w których przygotowywali się do zawodu kapłani uzdrowiciele oraz kapłanki akuszerki, i w których już wtedy prowadzono oddziały porodowe, pierwszej pomocy, medycyny paliatywnej oraz hospicja. Armia egipska dysponowała własnymi szpitalami polowymi i własnymi zespołami medyków. Egipcjanie najczęściej przy świątyniach zakładali cenne ogrody botaniczne, w których uprawiali rośliny przeznaczone na leki. Lekarstwa przygotowywali z dużą starannością, w specjalnych pomieszczeniach, ściśle wedle receptury, wykorzystując do tego rośliny zielarskie, minerały i tkanki zwierzęce. Podobno wykorzystywali oni jedną trzecią leków znanych nam dzisiaj. Zresztą wytwarzali je tak, jak czyni się to obecnie. Ze środków mineralnych stosowano sole miedzi (na wymioty), sole ołowiu (w celach kosmetycznych), natron, sól morską itd. ${ }^{61}$; ze środków pochodzenia zwierzęcego - prócz miodu - wykorzystywano w lecznictwie mleko różnych zwierząt, przeróżne tłuszcze

55 W. Giermaziak. Początki farmacji w cieniu piramid...

56 W Egipcie stworzono system kanalizacji. Nie wolno było zanieczyszczać ziemi gnijącymi ciałami, zwłoki balsamowano, istniały oględziny mięsa, wodę w późniejszych czasach pito przegotowaną i filtrowaną, bardzo dbano o higienę osobistą, stosowano enemy i higieniczny tryb życia.

57 K. Hanisz. Z historii leków. Inhalacje. „Bez Recepty” 2005, nr 3, s. 32-34.

58 Dawni egiptolodzy mieszali medycynę egipską z magią. Nieporozumienie wynikało m.in. stąd, że w staroegipskim ten sam wyraz oznaczał lekarza i magika. Grecki wyraz $\mu \alpha ́ \alpha$ o o oznacza szarlatana lub czarownika, natomiast Egipcjanie przez podobny wyraz rozumieli uczonego. Za: W. Szumowski. Historia medycyny..., s. 49.

59 Leczono wszystkie schorzenia i dolegliwości - od bólu zęba i dziąseł począwszy, poprzez astmę, miażdżycę, obniżenie odporności, kończąc na skomplikowanej trepanacji czaszki. Za: W. Szumowski. Historia medycyny..., s. 49.

60 Jedną z pierwszych znanych kobiet-lekarek była Peseshet, żyjąca w okresie IV dynastii, nosząca tytuł „zarządcy kobiecych lekarzy”. Pierwszą zaś znaną kobietą uczoną-lekarką była Merit Ptah (ok. 2700 r. p.n.e.) - zob. Nowy leksykon PWN. Warszawa: Wydawnictwo Naukowe PWN, 1998.

61 W. Szumowski. Historia medycyny..., s. 55. 
zwierzęce, rybie i ptasie, żółć, różne rodzaje krwi, mięsa, skóry, włosów, rogów, kopyt, kału, także całe owady, jak na przykład kantarydy, robaki, żmije, jaszczurki itp. ${ }^{62}$. Egipcjanie byli niezwykle biegli w opatrywaniu i leczeniu ran, które kurowali za pomocą żywic, skał i metali, co najmniej dwóch środków o działaniu antybakteryjnym oraz miodu, znanego powszechnie jako środek o właściwościach antywirusowych, antygrzybiczych i antybakteryjnych (miód, powodując odwodnienie, drogą osmozy tworzy warunki niesprzyjające rozwojowi drobnoustrojów). W podobny sposób leczono wrzody i oparzenia. Badania mumii egipskich wykazały, iż w przeszłości występowały potencjalnie śmiertelne urazy, które jednakże się zagoiły ${ }^{63}$. Świadczy to niezbicie o tym, że starożytni Egipcjanie byli znakomitymi ratownikami ludzkiego życia. Środki lecznicze przepisywali ${ }^{64} \mathrm{w}$ różnej postaci. Znali oni z całą pewnością roztwory, wlewki, wywary, syropy, emulsje i mazidła, plastry, kremy, maści, płukanki do ust; posiadali krople do oczu (zakrapiali je za pomocą ptasich piórek), pigułki, proszki, kompresy, tabaczki, a także czopki na schorzenia ginekologiczne i rektalne. Byli wynalazcami enemy. Na dolegliwości układu oddechowego ordynowali leki do inhalacji - wylewane na gorące kamienie i wdychane przez nos i usta za pomocą trzciny pustej w środku ${ }^{65}$. Umiejętnie stosowali techniki znane współczesnej farmacji - zagęszczali, rozcieńczali, miażdżyli, aby odpowiednio uwolnić zawartą substancję, potrafili konserwować sporządzane specyfiki. Jako pierwsi w charakterze metody leczniczej stosowali aromaterapię. Wymyślili też kosmetyki wieloskładnikowe. Obecnie wielkie światowe laboratoria kosmetyczne dokonują analiz starożytnych receptur, aby je wykorzystać na potrzeby współczesnego rynku kosmetologicznego ${ }^{66}$.

\section{Lecznictwo greckie i rzymskie}

Wysoka cywilizacja starożytnych Greków i Rzymian znalazła odbicie w licznych bezcennych księgach, w których zawarta została ogromna wiedza na temat roślin leczniczych ${ }^{67}$. A były to księgi Teofrasta z Eresos (370-287 p.n.e.), Dioskuridesa Pedianosa (I w.), Pliniusza Starszego (23-79 n.e.), Galena (130-201 n.e.). Warto pokrótce przyjrzeć się temu dorobkowi intelektualnemu.

Starożytni Grecy byli spadkobiercami wiedzy medycznej wypracowanej przez Egipcjan oraz społeczności znajdujących się w kręgu rozwiniętej kultury egejskiej ${ }^{68}$. Rozkwit nauk medycznych przypada u nich na okres V i IV wieku p.n.e. Lecznictwo praktyczne było związane $\mathrm{z}$ kultem religijnym ${ }^{69}$ i początkowo skupiało się wyłącznie

\footnotetext{
62 Ibidem, s. 55.

63 W. Giermaziak. Początki farmacji w cieniu piramid...

64 Sposób przepisywania lekarstw był podobny do dzisiejszego - środek podstawowy, środek pomocniczy, środek obojętny, nadający lekarstwu postać, a także środek poprawiający smak i zapach.

65 K. Hanisz. Z historii leków. Inhalacje...

66 W. Giermaziak. Początki farmacji...

67 Na ten temat zob. Historia medycyny. Wyd. 2 popr. i uzup. Red. T. Brzeziński. Warszawa: Wydawnictwo Lekarskie PZWL, 1995.

68 W. Szumowski. Historia medycyny...

${ }^{69}$ Grecy wykorzystywali także właściwości narkotyczne oraz toksyczne roślin w celach obrzędo-
} 
w świątyniach. Z czasem zrezygnowano z magii, szczególnie zaś z teurgii ${ }^{70}$ i praktykom lekarskim nadano świecki charakter (w VI wieku p.n.e.). Wykształciły się specjalizacje osób trudniących się sporządzaniem leków. Pojawili się farmakopole - osoby odpowiedzialne za ich przygotowanie. Mimo, iż w starożytnej Grecji medycyna stała na dość wysokim poziomie, trudniono się zielarstwem, a pasterzy uprawiających zioła nazywano pogardliwie trucicielami ${ }^{71}$. Wyszukiwaniem, zbieraniem, suszeniem, krajaniem ziół zajmowali się krajacze korzeni (ryzotomowie) ${ }^{72}$. Zioła sprzedawano w specjalnych składach, które nazywano apotheke (od gr. $\dot{\alpha} \pi \circ \theta \dot{\eta} \kappa \eta$ 'przechowywać') Starożytni Grecy umiejętnie reklamowali zarówno własne apteki, jak i produkty - do kupna specyfików zachęcali i wizualnie, umieszczając na ścianach freski oraz celne napisy, i „dźwiękowo”, wynajmując heroldów obwieszczających m.in. przybycie statków wiozących surowce lecznicze oraz wina ${ }^{74}$. Wiele nazw łacińskich zioła zawdzięczają greckim nazwom ludowym, na przykład nazwa naukowa krwawnika pospolitego używanego do tamowania krwawienia wywodzi się od imienia Achillesa, któremu w boju towarzyszył Patrokles. Grecy nie tylko opisywali właściwości uzdrawiające ziół, lecz koncentrowali się także na opisie ziół trujących, na które poszukiwali antidotum drogą eksperymentów na ludziach ${ }^{75}$.

Za prekursora współczesnej medycyny uchodzi Hipokrates z Kos (460-370); jest nazywany jej „ojcem”. Racjonalne idee i metody szkoły Hipokratesa znane są z dzieła Corpus Hippoctareum, które stanowi zbiór niespełna siedemdziesięciu pism lekarskich pochodzących z około IV wieku p.n.e., zebranych już po śmierci uczonego. Hipokrates stworzył podstawy nauki o płynach ustrojowych - krwi, śluzie, żółci, czarnej żółci. Jego zdaniem, zdrowie człowieka uzależnione było od stanu równowagi tych płynów. Ideą szkoły Hipokratesa była troska o zdrowie chorego (łac. salus aegroti suprema lex 'zdrowie najwyższym prawem') ${ }^{76}$. Naczelna zasada brzmiała natomiast: nie szkodzić choremu, lecz wspomagać naturalne procesy zdrowienia. Duży nacisk Hipokrates kładł na profilaktykę - zalecał dietę i higienę. Starożytny lekarz oparł medycynę na racjonalnych zasadach i nauka jego „nie ma sobie równej pod względem troski o chorego, obserwacji lekarskiej i logicznego wyciągania wniosków prognostycznych. Wywarła ona przemożny wpływ na medycynę światową przez wiele stuleci. Hipokrates sporządził bardzo dokładne opisy objawów chorobowych oraz niezwykle bogaty spis

wych. Wywarów z roślin trujących używali m.in. do wykonywania wyroków śmierci.

70 Teurgia to forma magii polegająca na zmuszaniu bóstwa do pożądanego działania.

71 Por. M. Barosiak. Wąż Eskulapa, laska Asklepiosa i krew Gorgony. Cz. II. „Bez Recepty” 2001, nr 5.

72 Zob. K. Hanisz. Polihymnia u Asklepiosa. Cz. I: Historia farmacji. „Bez Recepty”, lipiec 2001;

K. Hanisz. Polihymnia u Asklepiosa. Cz. II: Historia farmacji. „Bez Recepty”, październik 2001.

73 Z. Wolniak. Historia pierwszych aptek. „Bez Recepty”, lipiec 2003.

74 K. Hanisz, M. Ewich. Z dziejów reklamy aptekarskiej. „Bez Recepty” 2003, nr 10, s. 22-23.

75 Władca Pergamonu Attalos III w obawie przed otruciem, sadził w ogrodzie toksyczne rośliny, m.in. ciemiężycę, lulek, szalej, bieluń, z których następnie sporządzano wywary, po czym podawano skazańcom, aby obserwować ich reakcję na nie. Król Pontu Mitrydades V przygotowywał natomiast odtrutkę, na którą usiłował uodpornić swój organizm, bowiem również chorobliwie bał się otrucia - za: Zielnik dla każdego..., s. 9.

76 Wielka encyklopedia powszechna PWN. T. 1-12. Warszawa: Państwowe Wydawnictwo Naukowe, 1960-1968. 
leków. Był wielkim zwolennikiem ziołolecznictwa, zioła zaś zalecał stosować bez jakiegokolwiek przetwarzania $\mathrm{z}$ uwagi na optymalną ilość zawartych w nich substancji leczniczych ${ }^{77}$. Idee Hipokratesa rozwijane były m.in. przez Dioklesa (ur. ok. 350 r. p.n.e.), autora pierwszej książki o anatomii.

Równie wybitnym uczonym greckim był Teofrast z Ereos (ok. 370-287 p.n.e.), uczeń Arystotelesa. Rozbudował on metodę obserwacji naukowej i stosował ją w wielu dziedzinach - badaniach dotyczących biologii, medycyny, meteorologii oraz w rozważaniach etycznych i charakterologicznych. Największe zasługi Teofrast położył jednak na polu biologii. Formułując różnice między światem zwierzęcym i roślinnym, skupił się na badaniu świata roślin i zyskał dzięki temu miano „ojca botaniki”. Zajmował się przede wszystkim systematyką, morfologią, geografią, ekologią i fizjologią roślin (wydzielił trzy organy tych ostatnich: korzeń, łodygę i liść). Dążył do ustalenia terminologii botanicznej. Wprowadzony przez niego podział świata roślinnego na cztery grupy: rośliny zielne, krzewiny, krzewy, drzewa przetrwał w nauce aż do XVI wieku. Teofrast opisał około 500 gatunków. Pozostawił bogaty dorobek piśmienniczy, m.in. Historia plantarum (Badania nad roślinami) w dziewięciu księgach i De causis plantarum (Przyczyny powstawania i rozwoju roślin) w sześciu księgach. Uważany jest ponadto za prekursora ekologii i geografii roślin ${ }^{78}$.

Wybitnym greckim lekarzem, farmakologiem i botanikiem, pracującym w Rzymie w służbie cesarzy Nerona i Wespazjana, był Dioskurides Pedianos (ok. 40-90), który podczas wypraw wojennych opisywał działania lecznicze kilkuset gatunków roślin, wprowadzając tym samym ziołolecznictwo na nauk medycznych. Opisał on szereg produktów zwierzęcych o znaczeniu dietetycznym i leczniczym. Jest autorem pięciotomowego dzieła De Materia Medica, uznawanego za najważniejszą księgę o roślinach zielarskich czasów starożytnych, użyteczną do XVII wieku i stanowiącą punkt wyjścia do opracowania pierwszych farmakopei. Jego nazwiskiem nazwano rodzinę roślin jednoliściennych Dioscoreaceae ${ }^{79}$.

W starożytnym Rzymie uznani medycy często miewali greckie korzenie. Jednym z takich był Asklepiades (124 r. p.n.e. lub 129 r. p.n.e. - 40 r. p.n.e.) - zwolennik atomizmu epikurejskiego i mechanicznego wyjaśniania czynności organizmu. Medyk ów stosował proste i naturalne środki lecznicze, takie jak dieta, ruch, świeże powietrze, kąpiele, masaże, kuracje wodne i napotne. W charakterze uniwersalnego środka przypisywał wino. Wywarł wielki wpływ na dalszy rozwój medycyny; głosił zasadę leczenia „tuto, celriter, iucunde” ('pewnie, szybko i przyjemnie') ${ }^{80}$.

Ważnym uczonym i encyklopedystą był Aulus Cornelius Celsus ( 50 r. p.n.e. 7 r. n.e.) - autor wielkiego dzieła encyklopedycznego Artes, które zawierało 8 ksiąg O medycynie (De Medicina). Choć Celsus nie był lekarzem, to udało mu się niezwykle trafnie dokonać kompilacji ówczesnego dorobku wiedzy medycznej. Jego dzieło stało się klasycznym podręcznikiem, do XVIII wieku wielokrotnie tłumaczono je na różne języki, jest cenione do dziś przez patologów.

\footnotetext{
7 Ibidem.

78 Ibidem.

79 Zob. Wielka encyklopedia powszechna PWN. T. 3..., s. 54.

80 Ibidem.
} 
W I wieku praktykował Pakkios Antiochos, który zdobył majątek dzięki sprzedaży pewnego specyfiku, którego recepturę utrzymywał w sekrecie. Scribonius Largus w I wieku n.e. pozostawił po sobie dzieło De compositione medicamentorum (O sporzadzaniu leków). Na przełomie wieków II i III działał Sekstus Empiryk, przedstawiciel szkoły sceptyków niewierzących w wykrywanie prawdziwych przyczyn chorób i ograniczających się do obserwacji objawów. Twórcą monumentalnego dzieła Historia Naturalis (Historia naturalna), złożonego z 37 ksiąg o charakterze encyklopedycznym, jest Pliniusz Starszy (Caius Plinius Secundus, 23-79 n.e.). Księgi 12-27 obejmują botanikę, ogrodnictwo, rolnictwo i leki roślinne, księgi 28-32 - leki pochodzenia zwierzęcego, zaś księgi 33-37 - minerały. Dzieło to stanowiło główne źródło informacji aż po czasy renesansu i zawierało opis blisko 1000 gatunków roślin.

Najwybitniejszym lekarzem rzymskim greckiego pochodzenia był chirurg, patolog i anatom Galen z Pergamonu (Claudius Galenus, ok. 130 n.e. - 200 n.e), przyboczny lekarz cesarzy i główny lekarz gladiatorów ${ }^{81}$. Wywarł on ogromny wpływ na późniejszy rozwój nauk medycznych średniowiecza i renesansu. Galen pozostawił po sobie ogromny dorobek, m.in. w postaci pism medycznych i farmaceutycznych, z których największe znaczenie mają Therapeitice (Metoda lecznicza), nazwane później Megatechne, oraz Techneiatrike (Sztuka lekarska), przemianowane następnie na Mikrotechne. Zdaniem Galena, cztery elementarne jakości występują także w zasadniczych cechach innych leków pochodzenia roślinnego, zwierzęcego lub mineralnego, tj. pieprz jest gorący, mięta i opium zimne, wino i cebula - gorące ${ }^{82}$. W oparciu o obserwacje wpływu różnych środków na organizm człowieka wprowadził cztery stopnie zimna ${ }^{83}$. Prócz tego wniósł niezwykle cenny wkład do terapii. Używał przy tym wielu leków w myśl zasady Populus remedia cupit ('lud żąda leków') ${ }^{84}$. Wprowadził również szereg nowych środków leczniczych, opisał ponad 400 roślin leczniczych, usystematyzował nagromadzone przez stulecia przepisy sporządzania leków ${ }^{85}$, a także badał sam i zalecał empiryczne badanie ich skuteczności - stworzył więc podwaliny farmacji. Galen stosował wszystkie znane leki wschodnie, a także sporo europejskich. Opracował metody sporządzania leków, na których opierała się niemal cała terapia przez następne piętnaście wieków ${ }^{86}$. W jego receptach odnajdujemy wiele środków mineralnych: związki ołowiu, miedzi, żelaza, arszeniku, sól morską, sól kamienną, gips, glinkę, siarkę, ałun, sodę, lapis lazuli, jaspis, malachit. $Z$ arsenału środków leczniczych pochodzenia zwierzęcego, oprócz powszechnie znanych, takich jak mleko, serwatkę, masło, tłuszcze, włączył do terapii jądra, jajniki (jest prekursorem dzisiejszej opoterapii), mięso, szpik, ślinę, jaja itd. Był natomiast zdecydowanym przeciwnikiem stosowania potu, moczu, krwi miesiączkowej, gnoju, które uważał za obrzydliwe. Jego ulubionym środkiem na dole-

\footnotetext{
81 Ibidem.

82 W. Szumowski. Historia medycyny..., s. 147.

83 Galen uważał, że choroby powstające z niewłaściwego składu cieczy, należy leczyć w oparciu o zasadę „contraria contrariis” środkami przeciwnymi, jak zimne i ciepłe kąpiele, okłady, powietrze - za: W. Szumowski. Historia medycyny..., s. 148.

84 W. Szumowski. Historia medycyny..., s. 148.

85 Ibidem, s. 148.

86 Wielka encyklopedia powszechna PWN. T. 4..., s. 84.
} 
gliwości żołądkowe był pieprz ${ }^{87}$. Przepisywał aloes oraz diacodion (syrupus diacodion 'ulepek makowy'). Galen był twórcą wiedzy o postaciach leków - twierdził, że postać, $\mathrm{w}$ jakich są podawane, determinuje ich działanie. Wprowadził nowe postacie leków, m.in. proszki, wyciągi, nalewki na wodzie, winie i occie, mazidła, noszące do dziś nazwę preparatów galenowych ${ }^{88}$, inaczej galeników (tj. leków z surowców pochodzenia roślinnego, zwierzęcego i mineralnego otrzymywane drogą ekstrakcji); dokonał podziału substancji leczniczych na maści, kremy, papki. Zalecał środki do pędzlowania, na kichanie, do żucia, wstrzykiwania, wlewania, wziewania, lewatywy, plastrów gorczycznych, środki przyżegające, proszki do zębów, czopki, a także krążki maciczne ${ }^{89}$. Do nauk medycznych włączył kosmetykę.

\section{Lecznictwo bizantyjskie}

W starożytnym Bizancjum działało wielu znakomitych lekarzy, filozofów, botaników, ale w zasadzie wnieśli oni niewiele nowego do rozwoju nauk medycznych, bazując na bogatym dorobku swoich poprzedników ${ }^{90}$. Najwybitniejszymi byli: biegły chirurg Oribarius (Oribasios, Oribasism Oribaso, 325-403) - autor potężnego dzieła medycznego w 70 tomach Zbiory lekarskie, będącego cenną encyklopedią medyczną, oraz czterotomowego poradnika samoleczenia Lekarstwa domowe; Aleksander z Tralles (ok. 525-605) - patolog i internista, twórca dzieła Dwanaście ksiąg na temat medycyny poświęconego w całości leczeniu chorób wewnętrznych, oraz chirurg Paweł z Eginy (Paulus Aegineta, Aegina, 625? - 690?), który opracował encyklopedię medyczną Epitomes iatrikes biblio hepta, stanowiące podsumowanie zachodniej wiedzy medycznej, która zdobyła wręcz niezwykłą popularność w medycynie arabskiej i europejskiej.

\section{Lecznictwo arabskie}

Średniowieczna medycyna arabska była spadkobierczynią dziedzictwa medycyny różnych kultur - perskiego, hinduskiego, syryjskiego, mezopotamskiego, greckiego i egipskiego ${ }^{91}$. W XI wieku różniła się już od tej antycznej, była dużo bardziej zaawansowana niż poprzedzająca ją wiedza z kręgu kultury śródziemnomorskiej, a przede wszystkim wyprzedzała znacznie ówczesną medycynę europejską ${ }^{92}$. Arabowie stworzyli nadzwyczaj postępową i bogatą literaturę medyczną oraz system kształcenia lekarzy, który potwierdzał wiedzę dyplomem. Podczas studiów medycznych w ramach zajęć studenci musieli odbywać praktykę w ogrodzie i poznawać rośliny lecznicze. Lekarze wywodzili się spośród innych nacji, głównie Syryjczyków, Persów i Greków.

\footnotetext{
87 W. Szumowski. Historia medycyny..., s. 148.

88 Por. J. Pluta, D. Haznar-Garbacz, B. Karolewicz, M. Fast. Preparaty galenowe. Wrocław: MedPharm Polska, 2010.

89 A. Drygas. Zarys dziejów farmacji. Z elementami zagadnień metodologicznych dla studentów farmacji. Gdańsk: Akademia Medyczna, 1994.

90 W. Szumowski. Historia medycyny..., s. 148.

91 Opracowano na podstawie: W. Szumowski. Historia medycyny..., s. 148.

92 Ibidem.
} 
Ekspansja muzułmańska wpłynęła w dużej mierze m.in. na rozwój handlu środkami leczniczymi i wymianę wiedzy medycznej. W Koranie i w hadisach wartości ludzkiego zdrowia poświęcono wiele wersetów, zaś Mahomet polecał, aby zdrowie darzyć szczególnym szacunkiem; zwracał się do chorych, aby domagali się leków, a do lekarzy - by je tworzyli ${ }^{93}$. Prorok nakazywał również inwestować w badania naukowe. Zarówno Koran, jak i Sunna zawierają wiele wskazań na temat higieny, a tym samym profilaktyki chorób. W muzułmańskich szpitalach $\mathrm{z}$ uwagi na zachowanie właściwej higieny żywienia organizowano odrębne kuchnie oraz opracowywano specjalną dietę zalecaną chorym. W VIII wieku Arabowie stworzyli i rozwinęli znakomity system lecznictwa otwartego. Zakładali pierwsze szpitale publiczne, także o charakterze dzisiejszych klinik medycznych, pierwsze szpitale psychiatryczne oraz apteki, w których wydawano leki na podstawie recept lekarskich. Do lecznictwa włączono farmakognozję ${ }^{94}$. Dorobek antyczny Dioskuridesa Arabowie wzbogacili o wiedzę pochodzącą z Indii i Chin oraz z własnych doświadczeń. Wnieśli tym samym nieoceniony wkład w rozwój farmacji i ziołolecznictwa ${ }^{95}$. Uczonym muzułmańskim zawdzięczamy odkrycie destylacji, w wyniku której otrzymuje się olejki eteryczne. Arabowie wzbogacili asortyment leków wieloma roślinnymi surowcami z Indii i Chin. Wprowadzili w rejonie Morza Śródziemnego uprawę ryżu, trzciny cukrowej i bawełny. Opracowali nowe formy leków, na przykład syropy, wody aromatyczne, spirytusy lecznicze. Zarysował się wyraźny podział na medycynę i farmację ${ }^{96}$.

Jednym z najznamienitszych lekarzy muzułmańskich okresu średniowiecza był Rhazes (Abu Bakr Muhammad ibn Zakarijja ar-Razi, 865-932), uznawany za ojca medycyny eksperymentalnej (prowadził m.in. doświadczenia w alchemii). Rhazes traktował sztukę lekarską jako „sztukę, która poświęciła się zachowaniu zdrowego ciała $\mathrm{w}$ walce $\mathrm{z}$ chorobą" ${ }^{97}$. Wskazywał na trzy ważkie aspekty nauk medycznych: zdrowie publiczne, medycynę profilaktyczną i lecznictwo indywidualne. Motto Rhazesa było następujące: „Zwalczanie choroby może być zawsze osiągnięte przez stosowanie diety, a nie leków; unikaj stosowania leków złożonych wszędzie tam, gdzie wystarczą prostsze" ${ }^{\text {"98 }}$. Stworzył on także - co ciekawe - podwaliny pediatrii. Krąg jego zainteresowań naukowych był nader szeroki i obejmował higienę, epidemiologię, toksykologię oraz klimatologię.

Do kręgu wybitnych uczonych należeli Abu Rajhan Muhammad al-Biruni (9731048), który pozostawił wybitną Farmakognozję, w której odniósł się krytycznie do poglądów na temat leczniczego wpływu kamieni i minerałów, a także Ibn al-Bajtar - autor cenionej Księgi leków. Najsłynniejszym uczonym islamskim, lekarzem i filozofem, był Ibn Sina (980-1037) zwany Awicenną z Buchary, okrzyknięty ojcem medycyny nowożytnej; na podkreślenie zapewne zasługuje fakt, iż sławę medyczną zdobył

\footnotetext{
93 Ibidem.

94 J. Danecki. Co zawdzięczamy islamowi. [Online:] <http://www.opoka.org.pl/biblioteka/I/IR/co_ islamowi.html> (dostęp: 12.02.2016).

95 O tym A. Drygas. Zarys dziejów farmacji...

96 Ibidem.

97 P. Kardas. Najstarsze leki. „Żyjmy dłużej” 1999, nr 12.

98 Ibidem.
} 
on w wieku lat siedemnastu. Pozostawił po sobie 450 uczonych ksiąg, m.in. Kanon medycyny (używany w Europie do XVIII w.) i Księge uzdrowienia. Wprowadził do lecznictwa diety wyłącznie owocowe, masaże lecznicze, opisał wiele ich technik. Sporządził opis ośmiuset leków roślinnych - rodzimych i proweniencji egipskiej, perskiej, hinduskiej, tadżyckiej, syryjskiej, mezopotamskiej, greckiej ${ }^{99}$.

Warto uzmysłowić sobie fakt, iż cały dorobek intelektualny wypracowany w starożytności przez Greków i Rzymian Europa zawdzięcza wysoko rozwiniętej kulturze arabskiej, która nie tylko wzbogaciła go, ale i przechowała wiedzę medyczną (przekłady medycznych dzieł hellenistycznych na arabski). Dotyczy to szeroko pojmowanej powinności leczenia ludzi. Arabskie osiągnięcia w zakresie agrokultury przyniosły rozwój rolnictwa i upraw lasów w całej Europie. To właśnie Arabowie zaszczepili w Europejczykach zamiłowanie do zakładania ogrodów, w których hodowano nie tylko rośliny ozdobne (pozytywnie działające na psychikę), ale też przyprawowe (wspomagające trawienie, dodające aromatu) i lecznicze. Wielu arabskich botaników zyskało sławę w kręgu europejskim; do nich należał m.in. toledańczyk Ibn Wafid (zm. 1075) znany jako Abenguefith, któremu przypisuje się autorstwo dzieła Madżmu al-filaha (Zbiór o rolnictwie $)^{100}$.

\section{Lecznictwo żydowskie}

W medycynie żydowskiej na plan pierwszy wysuwa się higiena. O szczegółach mówią Święte Księgi Starego Testamentu oraz Talmud. Żydzi, podobnie jak Arabowie, rozwinęli kosmetologię, wytwarzając z roślin olejkodajnych cenne i kosztowne wonności. W Biblii można odnaleźć kilkadziesiąt nazw ziół. Odnajdziemy w niej też wzmianki o „niszczących” choroby właściwościach gleby. Według ówczesnych wierzeń gleba miała specyficzne właściwości odkażające. Wierzono, że ciała ludzi zmarłych na chorobę zakaźną po złożeniu do ziemi traciły swoje zakaźne cechy ${ }^{101}$.

\section{Średniowieczne lecznictwo w Europie}

Ziołolecznictwo kontynuowano w chrześcijańskich klasztorach w ramach tradycji zakonnej ${ }^{102}$. Ożywienie w tej dziedzinie nastąpiło dopiero w VI wieku, kiedy rzymski filozof i mnich Kasjodor (485-583) czynił wysiłki, aby zgromadzić i odtworzyć starożytną wiedzę medyczną. W klasztorach stworzył niezbędne warunki do kopiowania i analizowania ksiąg Galena i Hipokratesa oraz kontynuowania ich dzieła; przyczynił się do rozwoju medycyny klasztornej opartej na lekach roślinnych i wywiadzie lekarskim. Wybitne zasługi mieli w tej dziedzinie benedyktyni z Salerno ${ }^{103}$. W X wieku

\footnotetext{
99 J. Danecki. Co zawdzięczamy islamowi.

100 Ibidem.

101 Por. S. Russell. Antybiotyki..., s. 26. Por. M. Wasilewski. Minerał jako lek. Między starożytnościa a współczesnością. Warszawa: Oficyna Wydawnicza Rytm, 2008.

102 Zob. np. A. Cavelius, B. Frohn. Zioła w medycynie naturalnej. Przeł. P. Montusiewicz. Bremen: Mak, 2005.

103 W. Szumowski. Historia medycyny...
} 
powstała tam szkoła medyczna, która uważana jest za pierwowzór uniwersytetów (w czasie wojen krzyżowych misjonarze powracający z Ziemi Świętej zawijali do Salerno, aby leczyć swoje choroby i rany). Jednym z najwybitniejszych jej uczonych był Konstantyn Afrykańczyk z Kartaginy, podróżnik, autor prac, w których wymieniał 168 roślin leczniczych i ponad 200 leków. Mnisi uprawiali rośliny lecznicze w wirydarzach, sporządzali maści, wyciągi, wywary, nalewki, byli tym samym uzdrowicielami, opracowali bowiem szereg cennych receptur ziołowych i przepisów dietetycznych, które weszły na stałe do ludowej kultury medycznej ${ }^{104}$. Posiedli również sztukę prowadzenia ilustrowanych herbariów, które stały się katalogami roślin leczniczych (rozwój europejskiego ziołoznawstwa) $)^{105}$.

W średniowiecznej Europie, wyniszczanej przez pożary i epidemie, wraz z upadkiem kultury miejskiej nastąpił faktyczny upadek medycyny ${ }^{106}$. Zarówno chorzy, jak i medycy we wszystkim dopatrywali się działania sił nieczystych, nienaturalnych, ozdrowienia szukali w opatrzności Boskiej (teocentryzm), diabłach i aniołach. W sprawach zdrowia stosowano egzorcyzmy, magię, post, ofiarę, relikwie i modlitwę. Wiele chorób mało swoich patronów. Równocześnie nie przestrzegano żadnych zasad higieny (piętno grzechu na ciele ludzkim). Ziołolecznictwo stało się przede wszystkim domeną cudotwórców i czarownic, a bywało, że i sutenerów. Nastąpił długi okres degradacji ziół, a tym samym dobroczynnej fitoterapii. W puszczach przed okrucieństwem ówczesnego życia, a później przed Świętą Inkwizycją, zmuszone były skrywać się kobiety żywiące się, leczące i czarujące zbieranymi przez siebie leśnymi roślinami. Były wśród nich osoby o niezwykłej intuicji medycznej, które - jak stwierdza Szumowski - „łatwiej robiły nowe odkrycia niż napuszeni doctores medicinae”107. Kościół uznawał czarodziejstwo za „grzech przeciwny religii”, a papież Innocenty VIII wydał bullę nakazującą inkwizytorom prześladowanie czarownic.

W epoce Odrodzenia zakonnicy utracili wyłączność na leczenie ziołami. Pojawili się aptekarze, olejkarze, zbieracze ziól, a także lekarze-botanicy ${ }^{108}$. Rozpoczęto naukowe opisywanie nowych roślin i surowców leczniczych. Nie sposób wymienić tu wszystkich nazwisk znamienitych europejskich uczonych lekarzy i botaników działających w tym okresie. Na przestrzeni XIII i XIV wieku w wielu krajach europejskich utworzono pierwsze apteki nazywane "składami pieprzu” $i$,sklepami korzennymi” ${ }^{109}$. Wynalezienie druku sprzyjało rozpowszechnianiu wiedzy lekarskiej i farmaceutycz-

104 Układ gniazdowy i słownik słów kluczowych wybranych kategorii kultury. Medycyna ludowa. Red. Cz. Robotycki, W. Babik. Kraków: Wydawnictwo Uniwersytetu Jagiellońskiego, 2005; A. Paluch. Swiat roślin $w$ tradycyjnych praktykach leczniczych wsi polskiej. Wrocław: Wydawnictwo Uniwersytetu Wrocławskiego, 1984; prace Katarzyny Hanisz w magazynie „Bez Recepty”.

105 M. Kora. Zielona medycyna. Apiterapia, homeopatia, ziołolecznictwo. Warszawa: Oficyna Wydawnicza EKO-VITAL, 1996; Fitoterapia i leki roślinne. Red. E. Lamer-Zarawska et al. Warszawa: Wydawnictwo Lekarskie PZWL, 2007.

106 W. Szumowski. Historia medycyny...

107 Ibidem.

108 O tym: J. Majewski. Pierwsze apteki w grodzie Lecha. „Bez Recepty”, styczeń 2003; J. Majewski. Muzea farmacji i zbiory aptekarskie w Polsce. Poznań: Wydawnictwo Kontekst, 2006.

109 Z. Wolniak. Korzenie aptek i zawodu lekarskiego. „Bez Recepty”, kwiecień 2009; Z. Wolniak. Historia pierwszych aptek. „Bez Recepty”, lipiec 2003. 
nej, popularyzacji zielników o charakterze encyklopedii, które pełniły funkcję poradników lekarskich. Pierwszym zielnikiem drukowanym było włoskie Herbarium z 1481 roku Apuleiusa Platonicusa. Również w Polsce w XVI-XVII wieku ukazało się wiele cennych herbariów ${ }^{110}$. Najobszerniejszym, nadto najcenniejszym zielnikiem w Europie był wówczas zielnik opracowany przez doktora filozofii i medycyny Uniwersytetu Jagiellońskiego Szymona Syreniusza (Syreńskiego), wydany w 1613 roku w Krakowie, liczący 150 stron i zawierający opis 755 roślin mających uzdrawiające znaczenie. Do ważnych polskich opracowań należy ponadto Herbarz polski Marcina z Urzędowa (z połowy XVI wieku) ${ }^{111}$.

W epoce wielkich odkryć geograficznych wieków XV i XVI zioła oraz wiedza na tematy botaniczno-lekarskie stawały się coraz bardziej popularne ${ }^{112}$. Ze swych wypraw żeglarskich Hiszpanie i Portugalczycy przywozili niemało nieznanych dotąd gatunków roślin - z Ameryki m.in. drzewo chinowe (Cinchona L.), kakaowiec (Theobroma cacao L.), ipekakuanę (Carapichea ipecacuanha), wanilię (Vanilla Mill.), pieprzowiec (paprykę, Capsicum L.), senegę (krzyżownicę wirginijską, Polygala senega), ziemniaki (Solanum tuberosum L.), tytoń (Nicotiana L.), kukurydzę (Zea mays), a z Indii - liczne przyprawy korzenne i medykamenty azjatyckie. Miało to ogromny wpływ na rozwój ziołolecznictwa ${ }^{113}$. Rozpoczęto opracowywanie naukowych opisów nowych roślin i surowców leczniczych, popularyzowano wiedzę o lekach ${ }^{114}$.

Na przestrzeni kolejnych stuleci w Europie działało wielu uczonych przyrodników, opisujących korzystne działanie roślin. Jednym z nich był „aptekarz niezwykły” Samuel Heinrich Schwabe (1789-1875), wybitny astronom i znawca roślin, autor zielnika prezentującego około 3500 zachowanych roślin ${ }^{115}$.

\section{Chemia leków}

\section{Początki badań fitochemicznych}

Poniżej przedstawione zostaną ważniejsze kwestie związane z chemią leków na tle ogólnej historii lecznictwa. Opisane zostaną najbardziej istotne dla medycyny odkrycia dotyczące prowadzonych przez kilka stuleci badań substancji roślinnych, które zaowocowały rzetelnym opisem naukowym wyodrębnianych, a następnie syntetyzowanych, substancji leczniczych, przyczyniając się do rozwoju farmacji. Uczeni krok po kroku pracowali nad udoskonaleniem składu chemicznego leków oraz modyfikacją ich oddziaływań na organizm ludzki, poszukując preparatów, które mogłyby być bez-

\footnotetext{
110 J. Szostak. Farmakognozja, farmacja galenowa i aptekarstwo w renesansowych zielnikach polskich. Warszawa: Wydawnictwo Lekarskie PZWL, 2006.

111 Zob. L. Bartkowiak. Kształtowanie się aptekarstwa w Polsce (XIII-XX wiek). Studium historiograficzne. Poznań: Wydawnictwo Naukowe Akademii Medycznej im. Karola Marcinkowskiego, 2004.

112 Historia leków naturalnych. T. 1: Źródła do dziejów etnofarmacji polskiej. Red. B. Kuźnicka. Warszawa: Wydawnictwo Instytutu Historii Nauki, Oświaty i Techniki, 1986.

113 Fitoterapia i leki roślinne. Red. E. Lamer-Zarawska et al. Warszawa: Wydawnictwo Lekarskie PZWL, 2007.

114 K. Hanisz. Apteczki w polskich dworach i dworkach - historia farmacji...

115 S. Kucharski. Aptekarz zapatrzony w Słońce. „Bez Recepty”, czerwiec 2003.
} 
piecznie wykorzystywane w terapii medycznej i weterynaryjnej. Prześledzenie historii osiągnięć uczonych w zakresie chemii leków pozwoli na ujawnienie wydarzeń przełomowych dla lecznictwa.

Przełomem w dziejach leczenia przy pomocy substancji roślinnych była działalność naukowa żyjącego w latach 1493-1541 Paracelsusa (właśc. Philippus Aureolus Theophrastus Bombastus von Hohenheim), niemieckiego lekarza, chemika, przyrodnika i filozofa, profesora uniwersytetu w Bazylei. Był on jednym z prekursorów nowożytnej medycyny i twórcą jatrochemii, fitochemii i współczesnej farmakognozji. Paracelsus wyrażał pogląd, iż zadaniem alchemii jest nie tylko próba wykrywania sposobów zamiany jednych substancji w drugie, lecz przede wszystkim poszukiwanie metod sporządzania leków na konkretne choroby. Filozofia Paracelsusa była swoista - kierował się bowiem wiarą, iż Bóg dał ludziom lek (arcanum) na każde schorzenie, a w celu ułatwienia odnalezienia go - zsyłał znaki zewnętrzne (sygnatury). Jednak nie udało mu się wynaleźć panaceum na wszystkie choroby. Uczony ów głosił, iż „więcej niż z ksiąg Galena i Avicenny można się nauczyć medycyny od kata i czarownicy"116. Był on autorem słynnej maksymy: „Świat to apteka, a Bóg jest największym aptekarzem”. Paracelsus stworzył teorię zwaną quinta essentia (kwintesencja), zajmującą się związkami farmakodynamicznie aktywnymi, a więc - nieocenionymi - ciałami czynnymi roślin, które odgrywają istotną rolę w przywracaniu zdrowia. Opracował metodę przetwarzania surowców roślinnych, wyodrębniając z nich ową substancję aktywną. Teoria Paracelsusa stanowiła podwalinę badań fitochemicznych, których przedmiotem było wykrywanie związków farmakologicznie czynnych; z badań tych z czasem wykształciła się jatrochemia. Paracelsus jako pierwszy zastosował w leczeniu preparaty chemiczne, wprowadził nowe leki i ustalił zasadę ich dozowania ${ }^{117}$; włączył do medycznego obiegu rtęć, siarkę, alkohol, sól kuchenną, sole arsenu, miedzi, ołowiu i srebra. Na przełomie XVI i XVII wieku z alchemii (jako przednaukowej praktyki starożytnej) wyłoniła się dziedzina zwana jatrochemią (chemiatria, alchemia lekarska), której celem było wyjaśnianie procesów przebiegających w organizmach żywych i preparowanie leków ${ }^{118}$. Nadal jednak podstawę lecznictwa stanowiły naturalne środki roślinne, w których botanicy i lekarze, odkrywali nieznane dotąd właściwości, często podpatrując praktykujące znachorki.

W 1785 roku miało miejsce znaczące dla lecznictwa odkrycie. A mianowicie: pewien angielski lekarz, William Withering, zaobserwował, iż jedna z okolicznych wiejskich kobiet-zielarek uleczyła ciężko chorego, któremu on nie dawał szans na przeżycie $\mathrm{z}$ powodu objawów puchliny spowodowanej zastoinową niewydolnością serca ${ }^{119}$. Z bukietu zielarskiego znachorki wyodrębnił zioło, u którego stwierdził zarówno nieocenione własności lecznicze, jak i śmiertelnie trujące (powodujące bicie serca albo zatrzymanie jego akcji). Withering sporządził naukowy opis zastosowania naparstnicy purpurowej (Digitalis purpurea), jednej z roślin najbardziej znanych i cenionych w leczeniu chorób związanych z niewydolnością sercowo-krążeniową. Przez dziesięć lat

\footnotetext{
116 M. Kora. Zielona medycyna. Apiterapia, homeopatia, ziołolecznictwo..., s. 11.

117 Nowy leksykon PWN. Warszawa: Wydawnictwo Naukowe PWN, 1998, s. 1271.

118 Ibidem, s. 715.

119 M. Kora. Zielona medycyna..., s. 12.
} 
Withering prowadził intensywnie eksperymenty mające na celu ustalenie właściwych dawek leku, a następnie opublikował wyniki swoich badań ${ }^{120}$. Z czasem ujawniono, iż właściwości lecznicze zioła związane są digitoksyną (Digitoxinum) - glikozydem nasercowym $\left(\mathrm{C}_{41} \mathrm{H}_{64} \mathrm{O}_{13}\right)$, uzyskiwanym z liści naparstnicy purpurowej, działającym na mięsień sercowy, która powoduje szybszy i silniejszy jego skurcz oraz wolniejszy i pełniejszy rozkurcz (silniej działa na serce niewydolne niż zdrowe), co w rezultacie czyni pracę serca bardziej efektywną i stabilną, a także z digoksyną (Digoxinum) organicznym związkiem chemicznym $\mathrm{z}$ grupy glikozydów $\left(\mathrm{C}_{41} \mathrm{H}_{64} \mathrm{O}_{14}\right)$ uzyskiwanym z naparstnicy wełnistej (Digitalis lanata), stosowaną do leczenia zaawansowanej skurczowej, zastoinowej przewlekłej niewydolności serca, migotania i trzepotania przedsionków, napadowymi częstoskurczami nadkomorowymi, wadami zastawkowymi przebiegającymi z niewydolnością serca, kardiomiopatię niedokrwienną, a także jako lek pierwszego rzutu u dzieci z niewydolnością serca. Digoksyna zwiększa siłę i pobudliwość mięśnia serca, zwalnia przewodnictwo w węźle przedsionkowo-komorowym i zmniejsza częstość akcji serca; digoksyna wykazuje też wpływ na kanaliki nerkowe - dzięki hamowaniu pompy sodowej wtórnie zmniejsza sekrecję reniny, powodujące nasilenie efektu natriuretycznego, a poprzez następcze zmniejszenie wytwarzania angiotensyny - rozszerzenie naczyń. Obydwa glikozydy okazały się środkiem niosącym ratunek tysiącom, wcześniej nieuleczalnie, chorych.

Przełomowe było również wykrycie właściwości sporyszu (Secale cornutum), czego dokonał w 1808 roku amerykański lekarz John Stearns, dowiedziawszy się od wiejskiej akuszerki - niemieckiej emigrantki, iż sporysz jest środkiem ułatwiającym poród ${ }^{121}$. Sporysz to przetrwalniki pasożytniczego grzyba buławinki czerwonej (Claviceps purpurea) z rodziny gruzełkowatych (Hypocreaceae), atakującego zboża (żyto, jęczmień, pszenica, ryż ${ }^{122}$. Dziś wiadomo, iż zawiera on wiele alkaloidów: ergotaminę (Ergotaminum), ergobazynę (ergometrynę, Ergometrinum), a także aminokwasy: tyrozynę (Tyrosinum), tryptofan (Triptophanum), histydynę (Histidinum), leucynę (Leucinum), kwas asparaginowy (Acidum asparticum), betainę (Betainum) i aminy biogeniczne: histaminę (Histaminum) i tyraminę (Tyraminum). Ergotamina zawarta w sporyszu powoduje skurcz mięśni gładkich macicy i naczyń krwionośnych; stosowana bywa więc do powstrzymania krwawienia $z$ dróg rodnych i jako lek wspomagający leczenie bólu migrenowego. Sporysz był i jest stosowany w medycynie w charakterze środka wczesnoporonnego oraz przeciwmigrenowego, wykazuje też działanie psychodeliczne. Wcześniej, kiedy ziarna zboża nie były czyszczone, domieszka sklerot sporyszu w ziarnach i mące powodowały halucynacje (tzw. ogień świętego Antoniego, ergotyzm), przykurcze mięśni prowadzące do martwicy tkanek w wyniku niedokrwienia ${ }^{123}$. Z czasem lekarze zidentyfikowali toksyczne właściwości grzybka. Z uwagi na źródło ergotaminy wykorzystywany jest on obecnie do produkcji LSD (silnej substancji psy-

\footnotetext{
120 Ibidem....

121 Zielnik dla każdego..., s. 12.

122 R. Palusiński. Narkotyki. Przewodnik, Cz. 1: Soft - drugs: marijuana, LSD-25. Grzyby: historia, produkcja, sposób użycia, efekty, niebezpieczeństwa. Kraków: Total Trade \& Publishers, 1994.

123 Zatrucie sporyszem nazywano „ogniem św. Antoniego”.
} 
chodelicznej, stosowanej m.in. w walce z silnymi bólami nowotworowymi) i innych środków narkotycznych.

Surowce roślinne były i są niezwykle istotnym źródłem pozyskiwania leków. Dzisiaj wiemy, że efekt terapeutyczny roślin (tzw. „babskich lekarstw”) uwarunkowany jest obecnością w nich różnych związków chemicznych - często mających różną budową i wykazujących silne działanie biologiczne. Nie sposób opisać osiągnięć medycyny nie zwróciwszy uwagi na rolę surowców zielarskich w wytwarzaniu leków. Jeśli współcześnie uzyskuje się leki w sposób syntetyczny, to przecież ich podłożem były wcześniej substancje uzyskiwane z surowców naturalnych.

Prześledźmy kształtowanie się rozwoju farmacji doby chemii farmaceutycznej. Od wielu setek lat ludzkość znała silne działanie na organizm ludzki i zwierzęcy pewnych surowców roślinnych ${ }^{124}$. W Ameryce Południowej używano kurary ${ }^{125}$ do zatruwania strzał, odwar pietrasznika czyli cykuty (właściwie szczwołu plamistego, Conium maculatum L.), zawierający koniinę (Coniinum), był trucizną stosowaną w starożytnej Grecji. Ludy wschodnie znały odurzające własności opium, Aztekowie i Majowie - peyotlu, meksykańskiej odmiany kaktusa (Lophophora williamsii) uważanego za „świętą roślinę", a ludy Ameryki Południowej - liście kokainowca (krasnodrzewu pospolitego, Erythroxylum coca Lam.) ${ }^{126}$. Od dawien dawna znano właściwości uzdrawiające niektórych roślin, m.in. dziko rosnącej w Indii u stup Himalajów rauwolfii żmijowej (zgrzynu żmijowego, Rauvolfia serpentina), będącej źródłem rezerpiny (Reserpinum) - naturalnego alkaloidu wyizolowanego z korzenia tej rośliny ${ }^{127}$. Mechanizm działania rezerpiny polega na wypłukiwaniu katecholamin (neuroprzekaźników) i zapobieganiu ich gromadzeniu się w zakończeniach nerwów układu współczulnego, co wpływa na zniesienie przekaźnictwa w układzie współczulnym i rozszerzenie naczyń krwionośnych, a to z kolei sprzyja obniżeniu ciśnienia krwi. Rezerpina znalazła zastosowanie w leczeniu łagodnego nadciśnienia powiązanego z częstoskurczem zatokowym. $\mathrm{Z}$ uwagi na silne działanie uspokajające, używano jej długo w psychiatrii jako efektywnego leku przeciwpsychotycznego ${ }^{128}$. Skuteczność niektórych preparatów roślinnych wpłynęła zresztą na ich dużą popularność w świecie medycznym (na przykład wcześniej chinina $)^{129}$.

Na przełomie XVIII i XIX wieku nastąpił niezwykle dynamiczny rozwój chemii ${ }^{130}$. We wczesnym okresie rozwoju chemii organicznej uczeni zwrócili uwagę na możliwość wyodrębnienia licznych substancji leczniczych z surowców roślinnych. W kolejnym XIX stuleciu zaszły istotne zmiany w lecznictwie farmaceutykami. W drodze

\footnotetext{
124 M. Kora. Zielona medycyna...; Fitoterapia i leki roślinne...

125 Kurara to toksyna pozyskiwana jako wyciąg z kory kilku gatunków kulczyby (Strychnos toxifera, S. schomburgkii, S. cognes), z cebuli rośliny Burmannia lub ze śluzowatej substancji korzeni Cissus quadrialata.

126 J. Z. Ryn. Medycyna indiańska...

127 J. Thorwald. Dawna medycyna, jej tajemnice i potega...

128 Por. Encyklopedia zielarstwa i ziołolecznictwa. Red. H. Strzelecka, J. Kowalski. Warszawa: Wydawnictwo Naukowe PWN, 2000.

129 Por. P. Kardas. Najstarsze leki...

130 Zob. W. Bergandy. Od alchemii do chemii kwantowej. Zarys historii rozwoju chemii. Poznań: Wydawnictwo Naukowe UAM, 1997.
} 
doświadczeń chemicznych chemikom udało się uzyskać szereg ważnych z medycznego punktu widzenia alkaloidów w postaci czystej, stały się one przedmiotem badań strukturalnych i syntetycznych. Wkrótce na dobre skończyła się też „złota era środków roślinnych”. W lecznictwie na wielką skalę zaczęto stosować tzw. chemikalia lecznicze, czyli uzyskiwane w laboratoriach środki chemiczne przeznaczone do celów leczniczych, tj. syntetyki lecznicze.

Przytoczmy kilka najbardziej istotnych dla lecznictwa faktów ${ }^{131}$. Pierwszej izolacji jednorodnej chemicznie substancji leczniczej z surowca roślinnego dokonał niemiecki aptekarz Friedrich Wilhelm Sertürner (1783-1841). Ten przełom w nauce zapoczątkował rozwój chemii leków. Uczony został jednym z pionierów chemii alkaloidów; w 1805 roku prowadził badania nad opium, które ostatecznie zaowocowały wyodrębnieniem morfiny (Morphinum) ${ }^{132}$ (od imienia gr. boga snu - Morfeusza) i stwierdzeniem właściwości nasennych i przeciwbólowych preparatu.

Duży wkład w badanie alkaloidów wniósł francuski farmaceuta i chemik Pierre Joseph Pelletier (1788-1842). Wspólnie z innym uczonym - chemikiem i farmaceutą - Josephem Beinaimé Caventou odkrył bowiem strychninę (Strychninum) (1818) i chininę (Chininum) (1820) oraz otrzymał po raz pierwszy związek polijodkowy - trójjodek strychniny. Wcześniej Caventou odkrył także i dokonał opisu chlorofilu (Chlorophyllum) - zielonego barwnika roślin (1819). Strychnina (Strychninum) $\left(\mathrm{C}_{21} \mathrm{H}_{22} \mathrm{~N}_{2} \mathrm{O}_{2}\right)$ jest alkaloidem silnie toksycznym występującym w nasionach kulczyby wroniego oka (Strychnos nux vomica). Działa ona jako symulant, wyostrzając zmysły. Działanie strychniny polega na blokowaniu synapsy hamulcowej, co implikuje pobudzenie neuronów. Zgon następuje w wyniku skurczu tonicznego mięśni oddechowych. Strychnina bywa stosowana w lecznictwie w małych dawkach pod postacią azotanu jako środek pobudzający krążenie, oddychanie oraz w stanie osłabienia ${ }^{133}$. W Polsce azotan strychniny zawierał lek Cardiamid-Coffein, a także preparat witaminowy Ascenerin. Nux vomica znajduje zastosowanie w homeopatii ${ }^{134}$.

Chinina (Chininum) $\left(\mathrm{C}_{20} \mathrm{H}_{24} \mathrm{~N}_{2} \mathrm{O}_{2}\right)$ jest alkaloidem występującym z korze drzewa chinowego. Był pierwszy efektywny lek stosowany przeciw malarii - chorobie wywoływanej przez pasożyta z rodziny Plasmodium i roznoszonej przez ślinę komarów z rodziny Aedes, Culex, Anophelex. Chinina posiada również właściwości przeciwgorączkowe, przeciwzapalne i przeciwbólowe. Jej działanie polega na tworzeniu kompleksów z DNA zarodźca malarycznego (Plasmodium malariae), co w efekcie powoduje zaburzenie funkcjonowania jego komórek. Chinina jest jadem protoplazmatycznym dla zarodźca malarycznego. Współcześnie zastępują ją leki syntetyczne z uwagi na silne

\footnotetext{
131 Opracowano na podstawie: Farmakologia kliniczna. Red. A. Chodera, Z.S. Herman. Warszawa: Wydawnictwo Lekarskie PZWL, 2008; H. Schott. Kronika medycyny. Przeł. z niem. M. Dutkiewicz, B. Floriańczyk, A. Zaniewska. Warszawa: Horyzont, 2002; A. Royston. Sto największych odkryć medycznych. Poznań: Podsiedlik-Raniowski i Spółka, 1995; S. Russel. Antybiotyki..., L.P. Graham. Chemia leków...

132 Por. Nowy leksykon PWN..., s. 1577.

133 Wielka encyklopedia powszechna PWN....

134 B. Wasilewski, J. Czelej. Leksykon leków homeopatycznych. Warszawa: Split Trading, 1994.
} 
działania neurotoksyczne, wywołujące często uboczne nieodwracalne objawy zaburzenia wzroku i słuchu oraz zapalenia wielonerwowe.

W 1819 roku wyodrębniono atropinę (Atropinum) $\left(\mathrm{C}_{17} \mathrm{H}_{23} \mathrm{NO}_{3}\right)$ - optycznie nieczynną (racemiczną) mieszaninę alkaloidu hioscyjaminy (L-atropina), otrzymywanej z liści i korzeni pokrzyku wilczej jagody (Atropa belladonna); atropina jest alkaloidem tropanowym i łatwo wchłanianym $\mathrm{z}$ przewodu pokarmowego. $\mathrm{W}$ dawkach leczniczych poraża zakończenia nerwów parasympatycznych i pobudza ośrodki oddechowe. W medycynie znalazła zastosowanie jako środek przeciwskurczowy i przeciwbólowy w skurczach mięśni gładkich żołądka, pęcherza i moczowodów, działa jednocześnie rozkurczowo na jelita, przewody żółciowe. Hamuje wydzielanie ślinianek, gruczołów potowych i gruczołów w oskrzelach, dzięki czemu używana jest m.in. w leczeniu astmy skrzelowej. Atropina ma również zastosowanie w reanimacji. Przy jej pomocy leczy się m.in. blok przedsionkowo-komorowy związany z intensywną impulsacją przywspółczulną ze strony nerwu błędnego, a także usuwa skutki zatrucia glikozydami nasercowymi. W chorobach krążeniowych atropina działa obkurczająco na skórę. W premedykacji (farmakologicznym przygotowaniu chorego do operacji) używa się jej w celu zapobieżenia bradykardii wywołanej przez leki ogólno znieczulające. Jest bardzo ważnym środkiem w leczeniu zatruć inhibitorami cholinesterazy, tj. organofosforanami (gazami bojowymi serii G, np. sarinem) i insektycydami organofosforanowymi, a także muskaryną zawartą w niektórych gatunkach grzybów - jej działanie polega na kompetencyjnym wiązaniu się z receptorami muskarynowymi w mięśniach i na ich blokadzie. Atropina znajduje zastosowanie w diagnostyce okulistycznej (działa na mięsień rzęskowy zaburzając zdolność akomodacji, blokuje receptory muskarynowe zwieracza źrenicy) oraz w leczeniu chorób oczu - zapobiega powstawaniu zrostów podczas stanów zapalnych rogówki i tęczówki. W dawkach terapeutycznych atropina nie wywiera szkodliwego wpływu na ośrodkowy układ nerwowy, natomiast w dawkach toksycznych powoduje objawy psychotyczne i zaburzenia orientacji.

W 1820 roku uzyskano kofeinę (Coffeinum) - alkaloid purynowy $\left(\mathrm{C}_{8} \mathrm{H}_{10} \mathrm{~N}_{4} \mathrm{O}_{2}\right)$ występujący w kawie, orzeszkach cola, liściach herbaty jako teina, guaranie jako guaranina, w yerba mate (wysuszonych, zmielonych liściach ostrokrzewu paragwajskiego Ilex paraguariensis) jako mateina. Odkrył ją niemiecki chemik Freidrich F. Runge. Kofeina jest środkiem psychoaktywnym z grupy stymulantów. Wykazuje działanie pobudzające na cały ośrodkowy układ nerwowy, a szczególnie na korę mózgową zmniejsza uczucie zmęczenia, przyspiesza procesy myślowe, poprawia stan koncentracji, wyostrza spostrzegawczość i pamięć. Kofeina pobudza ośrodek oddechowy, naczynioruchowy i nerwu błędnego, czego wynikiem jest szybszy oddech, wzrost ciśnienia krwi, wzmożenie czynności serca. Kofeinę i inne pochodne metyloksantyny stosuje się do leczenia bezdechu u noworodków oraz regulacji rytmu serca. Używana jest ona również jako dodatek do środków leczniczych w preparatach na ból głowy (rozszerza naczynia krwionośne opon mózgowych). Kofeinę można przedawkować - wówczas obserwuje się silne pobudzenie psychiczne, drżenie mięśni, arytmię, ból głowy itd. $\mathrm{W}$ większych dawkach kofeina powoduje efekt na poziomie rdzenia kręgowego.

W 1826 roku wyodrębniono koniinę (Coniinum) $\left(\mathrm{C}_{8} \mathrm{H}_{17} \mathrm{~N}\right)$ - główny alkaloid piperydynowy szczwołu plamiastego (Conium maculatum). Koniina jest silnym jadem zwojowym, podobnym w działaniu do nikotyny: poraża zwoje autonomicznego ukła- 
du nerwowego, intensywnie działa na zakończenia mięśni ruchowych. Zgon następuje w wyniku paraliżu mięśni oddechowych. Toksyna wchłania się przez skórę i błony śluzowe. Koniina nie ma znaczenia leczniczego. W starożytnej Grecji stosowano ją jako truciznę dla skazańców (potocznie zwana cykutą).

W 1828 roku wyizolowano po raz pierwszy nikotynę (Nicotinum) $\left(\mathrm{C}_{10} \mathrm{H}_{14} \mathrm{~N}_{2}\right)$ - organiczny związek chemiczny z grupy alkaloidów pirydynowych zawarty w liściach tytoniu. Śladowe ilości nikotyny znajdują się także w pomidorach, bakłażanach i papryce. Nazwa nikotyny pochodzi od nazwiska francuskiego lekarza Jeana Nicota, zalecającego w XVI wieku tytoń jako lek. Nikotyna jest silnie uzależniającym narkotykiem. W niewielkich dawkach działa jako stymulant, przyczyniając się do wzmożonego wydzielania adrenaliny, co powoduje zanik uczucia bólu i głodu, przyspieszenie bicia serca, rozszerzenie źrenic, a także utrzymanie wysokiego poziomu dopaminy w mózgu (dlatego schizofrenicy z reguły dużo palą). Zażycie większych dawek blokuje działanie układu nerwowego, zaburza metabolizm i wywołuje znacznie silniejsze objawy niż inne narkotyki.

W 1832 roku odkryto alkaloid fenantrenowy wyodrębniony z opium - kodeinę (Codeinum), inaczej metylomorfinę $\left(\mathrm{C}_{18} \mathrm{H}_{21} \mathrm{NO}_{3}\right.$ ), metylową pochodną morfiny (Morphinum). W medycynie stosuje się na ogół fosforan kodeiny. Kodeina wchodzi w skład leków złożonych na ogół z kwasem acetylosalicylowym, paracetamolem, ibuprofenem, sulfogwajakolem i kofeiną. Wykorzystywana bywa jako środek przeciwkaszlowy i zmniejszający bóle klatki piersiowej wywołane uporczywym kaszlem (efekt wywołany jest przez działanie substancji na ośrodek mózgowy odpowiedzialny za oddychanie). Działa na organizm łagodnie uspokajająco, nie wywołują euforii, i lekko znieczulająco, wzmaga także działanie innych środków przeciwbólowych. Ma zastosowanie przeciwbiegunkowe. Częste używanie kodeiny nie wiąże się jednak z uzależnieniem.

Próby wyizolowania związków czynnych z kokainowca (krasnodrzewu pospolitego, (Erythroxylum coca Lam.) podejmowane były od końca XVIII wieku Sukces nastąpił dopiero w 1860 roku, kiedy Albert Niemann wyodrębnił z liści ${ }^{135}$ koki alkaloid tropanowy, który nazwał kokainą (Cocainum), inaczej metylobenzoiloekgoninę $\left(\mathrm{C}_{17} \mathrm{H}_{21} \mathrm{NO}_{4}\right)$. Był to kolejny przełom w medycynie. Kokaina dość szybko znalazła zastosowanie w chirurgii, a ściślej w anestezjologii jako środek znieczulający, opracowano różnorodne metody anestezji z jej użyciem, które zyskały aprobatę lekarzy na całym świecie. Jako pierwszy kokainę do znieczulenia miejscowego zastosował oftalmolog austriacki Karol Koller (1857-1944), który w 1884 roku zastosował jej rozcieńczony roztwór podczas operacji usunięcia zaćmy. Ludzie używali jej jednak powszechnie w charakterze antydepresantu -zyskała uznanie sławnego europejskiego psychoterapeuty Zygmunta Freuda. Dość szybko kokaina stała się popularna, a przede wszystkim była, niestety, mocno nadużywana - rozpoczęto jej sprzedaż w papierosach, napojach gazowanych, gumie do żucia, a w czystej postaci można ją było nabyć bez recepty w każdej drogerii. Sprzedawano preparaty galenowe z liści koki, a jednym z najbardziej znanych przetworów były wyciągi na czerwonym winie ${ }^{136}$. Kokainę okrzyknięto

135 K. Hanisz, J. Mularczyk. Z historii leków uzależniających. Liście koka i kokaina. „Bez Recepty”, kwiecień 2002.

136 Był to ulubiony napój wzmacniający wielu osobowości świata artystycznego oraz papieża Leona XIII - za: K. Hanisz, J. Mularczyk. Z historii leków uzależniających... 
lekiem na wszystko - na osłabienie ogólne, bóle dziąseł, brzucha, astmę, oparzenia, rany, żółtaczkę, a nawet cholerę. Bezkrytyczne stosowanie niebezpiecznej kokainy stało się szybko przyczyną narkomanii kokainowej wśród elit ${ }^{137}$. Z uwagi na silne właściwości narkotyczne kokainy w medycynie zastąpiono ją z czasem syntetycznymi środkami znieczulającymi, m.in. prokainą (nowokainą), tetrakainą, lidokainą i anestezyną. W farmacji stosowanie kokainy jako składnika leków ograniczone jest surowymi przepisami. Roztwór chlorowodorku kokainy stosuje się do znieczulenia miejscowego w laryngologii i okulistyce.

W 1887 roku niemiecki uczony Arthur Heffter jako pierwszy wyizolował i zidentyfikował meskalinę (Mescalinum) $\left(\mathrm{C}_{11} \mathrm{H}_{17} \mathrm{NO}_{3}\right)$ - organiczny związek chemiczny, alkaloid z szeregu fenyloetyloamin o właściwościach halucynogennych, który występuje naturalnie w kaktusach - peyotlu (Lophophora williamsii), san pedro (Echinopsis pachanoi) i Trichocereus bridgesii, a także w małych liściach w rodzinie bobowatych, m.in. w Acacia berlandieri. Meskalina jest silnym enteogenem (substancją psychoaktywną).

W 1880 roku wydzielono hioscyjaminę (L-atropina) $\left(\mathrm{C}_{17} \mathrm{H}_{23} \mathrm{NO}_{3}\right)$, która jest alkaloidem występującym w postaci izomerów optycznie czynnych w roślinach $\mathrm{z}$ rodziny psiankowatych (Solanaceae Juss.), pokrzyku wilczej jagodzie (Atropa belladonna L.), bieluniu dziędzierzawie (Datura stramonium L.), lulku czarnym (Hyoscyamus niger), mandragorze lekarskiej (Mandragora officinarum L.). Hioscyjamina łatwo przechodzi w odmianę optycznie nieczynną - atropinę (Atropinum). Jest oczywiście trująca. W medycynie stosuje się ją w postaci atropiny, ziół oraz wyciągów z liści i korzeni. Znosi ona wpływ nerwu błędnego na serce, działa hamująco na gruczoły wydzielnicze w przewodzie pokarmowym oraz gruczoły potowe i ślinowe, rozszerzająco na naczynia krwionośne skóry (uwolnienie histaminy), zaś rozszerzająco na źrenicę i zwyżkowo na ciśnienie śródgałkowe, blokująco na receptory muskarynowe. Liście bielunia używane bywają do wyrobu papierosów i proszków przeciwastmatycznych - zawarte $\mathrm{w}$ dymie związki hioscyjaminy wykazują działanie rozszerzające oskrzela. W dużych dawkach bieluń poraża obwodowy układ nerwowy, powoduje pobudzenie psychoruchowe, otępienie, omamy, śpiączkę i delirium.

W 1828 roku austriacki profesor farmacji Johann Andreas Buchner uzyskał niewielką ilość żółtej substancji z wyciągu kory wierzbowej (salix) ${ }^{138}$, organiczny związek chemiczny z grupy glikozydów fenolowych - połączenie saligeniny (alkoholu salicylowego) z glukozą -, którą nazwał salicyną (Salicinum), będącej prekursorem dzisiejszej aspiryny ${ }^{139}$, tj. kwasu acetylosalicylowego (acidum acetylsalicylicum). Dwa lata wcześniej dwaj włoscy uczeni - Brugnatelli i Fontana - wyizolowali wprawdzie niewielką ilość salicyny, ale była ona mocno zanieczyszczona chemicznie. W 1829 roku francuski chemik Henri Leroux uzyskał 30 g salicyny z 11,5 kg kory wierzbowej. W 1899 roku Feliks Hoffman, pracujący w koncernie Bayer, po raz pierwszy zastosował kwas acetylosalicylowy jako środek przeciwbólowy (usiłował nim leczyć ojca chorego na stawy). Wkrótce otrzymano chemicznie oczyszczony kwas salicylowy, który był lepiej

\footnotetext{
137 Ibidem.

138 Korę wierzbową w leczeniu zapaleń stawów stosował już Dioskurides.

139 K. Knypl. Miejsce aspiryny w codziennej praktyce lekarskiej. „Medycyna Rodzinna” 2003, nr 3-4.
} 
tolerowany przez pacjentów. Nadano lekowi nazwę aspiryna (od słów acetyl i spiric acid) i rozpoczęto jego powszechną sprzedaż bez recepty. W połowie XX wieku zaobserwowano, iż pacjenci zażywający aspirynę jako lek przeciwbólowy w postaci gumy do żucia nie ulegali atakom serca. Obserwacja ta utorowała aspirynie drogę do zastosowania w kardiologii w profilaktyce zawałów serca i udarów mózgu. Wkrótce ujawniono również mechanizm przeciwzapalnego działania aspiryny (hamowanie syntezy prostaglandyn $)^{140}$.

W końcu XIX wieku trwały badania prowadzące do uzyskania alkaloidów drogą syntetyczną. Pierwszym syntetycznym alkaloidem była koniina (1886); potem dokonano syntezy kofeiny (1895), nikotyny (1904), kokainy (1923), chininy (1944), strychniny (1948). Dalsze badania umożliwiły dokładne poznanie budowy wielu alkaloidów, uzyskanie ich syntezy. Bodźcem w poszukiwaniu syntetycznych produktów zastępczych stały się takie czynniki, jak wysoka toksyczność alkaloidów, niepożądane działania uboczne, a także kłopoty i koszty związane z uzyskaniem czystych preparatów. Poszukiwania w tym kierunku zapoczątkował niemiecki chemik Alfred Einhorn (1857-1917), któremu w 1905 roku udało się dokonać syntezy nowokainy - leku zastępującego kokainę. Nowokaina (prokaina, polokaina) to chlorowodorek p-aminobenzoesanu dwuetyloaminoetylowego $\left(\mathrm{H}_{2} \mathrm{~N}-\mathrm{C}_{6} \mathrm{H}_{4}-\mathrm{COO}-\left(\mathrm{CH}_{2}\right)_{2}-\mathrm{N}\left(\mathrm{C}_{2} \mathrm{H}_{5}\right)_{2} \cdot \mathrm{HCl}\right)$. Jest on lekiem znieczulającym miejscowo, o krótkotrwałym działaniu, stosowana do znieczuleń nasiękowych, nadoponowych i rdzeniowych ${ }^{141}$. Zbuforowany roztwór prokainy (tzw. geriokaina) był popularnym lekiem geriatrycznym o jednak niepewnej skuteczności. W 1930 roku otrzymano syntetycznie pierwszy lek zastępujący chininę - atebrynę (alkaloid), która była stosowana przez armię USA podczas II wojny światowej. Atebryna jest preparatem używanym głównie do zwalczania pełzaka malarii oraz pasożytów przewodu pokarmowego (glisty, tasiemce). Usilnie prowadzono też poszukiwania środków zastępujących morfinę, które zostały uwieńczone w roku 1939 syntezą dolantyny - pochodnej piperydyny, leku przeciwbólowego rozkurczającego mięśnie gładkie, wykazującego działanie odurzające na centralny system nerwowy. W 1937 roku w tracie poszukiwań łatwego w użyciu podczas operacji chirurgicznych i nieuzależniającego leku usypiającego niemieccy badacze Max Bockmühl i Gustav Ehrhart otrzymali opioidowy lek przeciwbólowy - polamidon (łac. dolor 'ból') - obecnie wykorzystywany jest on jako substytut heroiny w terapiach odwykowych.

\section{Fitoterapia - niezwykłe właściwości leków roślinnych}

Ziołolecznictwo (fitoterapia, fitofarmakologia, z gr. phyton 'roślina' i therapeuo 'leczę’) jest działem medycyny i farmakologii, który zajmuje się wytwarzaniem leków na bazie naturalnych lub przetworzonych surowców roślinnych oraz ich zastosowaniem zarówno w terapii, jak i profilaktyce chorób. Działanie lecznicze roślin rozumiane jest w medycynie tradycyjnej jako obecność w nich ściśle zdefiniowanych substancji

\footnotetext{
140 Ibidem.

141 M. Trąbska-Świstelnicka. Rozwój znieczulenia miejscowego w polskiej stomatologii. „Prace Historyczne" 2009, nr 4 (46).
} 
chemicznych mających określoną budowę i związane z nią działanie fizjologiczne ${ }^{142}$. Lecznicza jest każda roślina użyta przez człowieka lub zwierzę, w dowolnej postaci i w jakikolwiek sposób, jeśli wywiera określone działanie farmakologiczne. Pod pojęciem surowca roślinnego rozumie się dowolną część rośliny wykorzystywaną do celów leczniczych, zaś lekiem roślinnym mogą być - prócz samego surowca - wyciągi płynne lub suche z surowca albo też izolowane czyste związki chemiczne. Cechą charakterystyczną leków roślinnych jest to, iż nie występują w postaci czystej, ale towarzyszą im liczne naturalne związki chemiczne.

Leki roślinne różnią się od leków syntetycznych pochodzenia roślinnego tym, że te drugie zawierają czysty związek czynny, na przykład atropina czy efedryna stosowane bywają na ogół w postaci soli rozpuszczalnych w wodzie ${ }^{143}$. Lek roślinny miewa różne postacie farmaceutyczne w zależności od przeznaczenia i sposobu przygotowania. Wraz z rozwojem technologii farmaceutycznej zaczęto stopniowo wprowadzać coraz bardziej zróżnicowane formy leków mające zastosowanie przy wytwarzaniu preparatów syntetycznych. Szereg współczesnych leków wytwarza się nadal na bazie surowców roślinnych ${ }^{144}$. Infekcje wywoływane przez wirusy ze względu na wysoką zakaźność i możliwość poważnych powikłań, a także zgonów wśród małych dzieci, osób cierpiących na przewlekłe schorzenia układu oddechowego itp., są wskazaniem do stosowania leków pochodzenia roślinnego ${ }^{145}$. Ogromną zaletą leczenia surowcami roślinnymi jest to, iż $\mathrm{w}$ ich składzie istnieją związki, do których nasz organizm jest przyzwyczajony od tysiącleci. Polski znawca leków przygotowywanych na bazie roślinnej Jan Muszyński stwierdził, iż zawierają one związki optycznie czynne, natomiast związki otrzymywane sztucznie, nawet o takim samym składzie chemicznym, są optycznie obojętne, tzn. że "nie skręcają płaszczyzny światła spolaryzowanego" ${ }^{146}$. Środki optycznie czynne wykazują najczęściej działanie kilkanaście razy silniejsze niż takie same środki otrzymywane sztucznie. Leki roślinne charakteryzują się zawsze zespołowym działaniem, przez co należy rozumieć, iż poszczególne składniki potęgują wzajemnie swoją skuteczność. Leki roślinne cechuje określona zawartość witamin, soli mineralnych, garbników, olejków eterycznych i innych składników uzupełniających, które są niezbędne dla do prawidłowego funkcjonowania ustroju, a zwłaszcza trawienia i przyswajania spożytych pokarmów, wydalania i odtruwania produktów przemiany materii, jak również wzmacniania mechanizmów odpornościowych organizmu człowieka. Wraz z rozwojem chemii nastąpił silny wzrost liczby wyodrębnianych z surowca substancji czynnych o działaniu leczniczym, m.in. alkaloidów, gliko-

\footnotetext{
142 Ziołolecznictwo. [W:] Encyklopedia zdrowia. T. 1..., s. 457.

143 Fitoterapia i leki roślinne. Red. E. Lamer-Zarawska et. al. Warszawa: Wydawnictwo Lekarskie PZWL, 2007.

144 K. Hanisz. Ziołolecznictwo w medycynie ludowej. Cz. I. „Bez Recepty”, wrzesień 2002. [Online:] $<$ http://bez-recepty. pgf.com.pl/index.php?co=artyk\&id_artyk=782> (dostęp: 12.05.207); K. Hanisz. Ziołolecznictwo w medycynie ludowej. Cz. II: Fitoterapia magiczna. „Bez Recepty”, październik 2002. [Online:] <http://bez-recepty.pgf.com.pl/index.php?co=artyk\&id_artyk=765> (dostęp: 12.05.2010). $145 \mathrm{~K}$. Blecharz-Klin et al. Interakcje leków roślinnych stosowanych $w$ chorobach układu oddechowego. „Herba Polonica” 2005, nr 3-4 (51), s. 89-97. [Online:] <http://www.iripz.pl/ftp/51_3_4_05_10.pdf> (dostęp: 11.06.2010).

146 Zielnik dla każdego..., s. 13.
} 
zydów, flawonoidów, saponin, kwasów, garbników, goryczy, tanin, azulenów, olejków eterycznych itd. Odkryto właściwości lecznicze pektyn i śluzów, a także zawartych w roślinach składników mineralnych i licznych pierwiastków śladowych. Medycyna współczesna na coraz większą skalę stosuje leki naturalne i modyfikowane. Zestaw leków fitoterapeutycznych zawiera wyodrębnione z roślin związki chemiczne, związki wytwarzane przez drobnoustroje, na przykład antybiotyki, leki półsyntetyczne lub zmodyfikowane, oczyszczone mieszaniny związków roślinnych, płynne i stałe wyciągi roślinne, olejki eteryczne, gotowe mieszanki ziołowe, granulaty lub suche wyciągi rozpuszczające się $\mathrm{w}$ wodzie, specyfiki i preparaty jednorodne, zawierające jedynie składniki roślinne oraz mieszane $\mathrm{z}$ dodatkiem związków syntetycznych lub pochodzenia zwierzęcego, a także homeopatycznych. Pochodzenia roślinnego są najbardziej popularne leki: polopiryna (kwas acetylosalicylowy) i witamina C (kwas askorbinowy). Lecznictwo dysponuje licznymi preparatami naturalnymi i zobowiązane jest do ich umiejętnego łączenia z lekami syntetycznymi i chemioterapeutykami. Większość leków roślinnych charakteryzuje się powolnym działaniem oraz, co niezwykle istotne, małym prawdopodobieństwem wywołania niepożądanych objawów. Wyjątkiem są tu oczywiście leki uzyskiwane z roślin silnie toksycznych, zawierających alkaloidy lub glikozydy, jak sporysz (Secale cornutum), naparstnica (Digitalis L.), tojad (Aconitum L.), zimowit jesienny (Colchicum autumnale) itd.

Leki roślinne cechuje $\mathrm{e}^{147}$ : 1) synergizm między składnikami zawartymi w wyciągach roślinnych, 2) synergetyczna aktywność we współdziałaniu $z$ wieloma równolegle używanymi lekami syntetycznymi, 3) dobra resorpcja związków czynnych w przewodzie pokarmowym, 4) duża rozpiętość terapeutyczna, tj. duża różnica między dawką działającą a dawką toksyczną. Efektywność fitoterapeutyczną leków udowodniono naukowo w odniesieniu do wielu przypadków schorzeń, niekiedy nawet o nieustalonym podłożu. Stosowane są one w różnych jednostkach chorobowych, a wiele $\mathrm{z}$ nich poleca się dzieciom, osobom starszym, kobietom ciężarnym i karmiącym.

Leki roślinne są używane jako ${ }^{148}:$ 1) leki podstawowe, na przykład w osłabieniu mięśnia sercowego i wywołanej tym zastoinowej niewydolności krążenia, w zaburzeniach rytmu serca, bielactwie itd.; 2) leki pomocnicze w wielu jednostkach chorobowych, na przykład w przewlekłych chorobach nerek i wątroby, w stanach po WZW, w nieżytach jelit i żołądka, w miażdżycy, w niektórych chorobach narządu ruchu, chorobach skóry; 3 ) leki uzupełniające działanie środków syntetycznych i chemioterapeutyków, na przykład w gruźlicy, mało zaawansowanej cukrzycy, pewnych schorzeniach neurologicznych; 4) leki działające synergetycznie, czyli współdziałające z preparatami hormonalnymi i innymi, na przykład w klimakterium, cisawicy, przeroście gruczołu krokowego prostaty; 5) leki przemienne, zalecane wtedy, gdy wymagana jest czasowa przerwa w podawaniu preparatów pochodzenia syntetycznego, na przykład w łuszczycy; 6) leki ochronne, podawane równolegle z lekami syntetycznymi i antybiotykami, zmniejszające ich szkodliwe działanie na wątrobę i układ moczowy.

W celu zagwarantowania właściwego działania terapeutycznego leki ziołowe powinny odpowiadać ustalonym normom pod względem zawartości głównych związ-

147 Ziołolecznictwo. [W:] Encyklopedia zdrowia. T. 1..., s. 469.

148

Ibidem, s. 469. 
ków chemicznych czynnych w surowcach leczniczych, preparatach oraz specyfikach ziołowych. Zioła zawierają następujące składniki: witaminy, makro- i mikroelementy, związki śluzowe, związki saponinowe, kwasy organiczne, kwas salicylowy, kwas krzemowy, glikozydy, olejki eteryczne, związki flawonowe, związki garbnikowe, hormony roślinne (fitochromy), bisabolol, antyoksydanty, różne związki naturalne o własnościach przeciwnowotworowych. Alkaloidy to liczna grupa związków w organicznych pochodzenia roślinnego, cechujących się charakterem zasadowym, obecnością w cząsteczce pierścienia $\mathrm{z}$ heteroatomem azotowym (do nielicznych wyjątków należy m.in. efedryna) oraz mniej lub bardziej silnym działaniem na układ nerwowy zwierząt wyższych $^{149}$. Alkaloidy dzielą się na: 1) pochodne pirydyny (np. nikotyna, koniina, piperyna, anabazyna, lobelina), 2) pochodne tropanu (np. atropina, hioscyjamina, skopolamina, kokaina, tropakokaina), 3) pochodne chinoliny (np. chinina, cynchonina), 4) pochodne izochinoliny (np. alkaloidy opium: morfina, papaweryna, kodeina i in.; alkaloidy kurary: tubokuraryna, toksyferyna i in.), 5) pochodne indolu (np. strychnina, rezerpina, ergotamina, eseryna, brucyna), 6) pochodne puryny (np. kofeina, teobromina, teofilina). Alkaloidy obecne są tylko w niektórych gatunkach roślin; ujawniają się na ogół w postaci soli kwasów organicznych, na przykład jabłkowego, cytrynowego, winowego, rzadziej kwasów nieorganicznych, na przykład siarkowego, fosforowego, czasami jako połączenie typu na przykład estry, a wyjątkowo w postaci wolnych zasad alkaloidowych. Wykazują one silne działanie fizjologiczne na organizm zwierząt wyższych. Na ogół są toksyczne dla układu nerwowego. Niektóre z nich, na przykład akonityna, już w dawkach miligramowych wywołują śmiertelne zatrucia i człowieka i innych ssaków. Małe dawki alkaloidów wywierają często działanie pobudzające na określoną część układu nerwowego. Pewne alkaloidy, na przykład morfina, kokaina, wywołują stany euforii, ale często zażywane prowadzą do głębokiego uzależnienia. $\mathrm{Z}$ uwagi na swoiste działanie alkaloidy znalazły zastosowanie $\mathrm{w}$ medycynie jako środki przeciwbólowe, znieczulające, przeciwskurczowe, pobudzające ośrodek oddechowy, uspokajające. Są również niezwykle cennymi środkami pomocniczymi w badaniach układu nerwowego. W farmacji większość alkaloidów otrzymuje się z surowców roślinnych, drogą ekstrakcji odpowiednio dobranymi rozpuszczalnikami, a niektóre (efedrynę, lobelinę, papawerynę) wytwarzane są syntetycznie.

Glikozydy to złożone związki organiczne cukrów, hydrolizujące zawsze na cukier i składnik niecukrowy zwany aglikonem; są szeroko rozpowszechnione we florze i faunie, a obecnie można je otrzymywać również w sposób syntetyczny. Wiele glikozydów znalazło zastosowanie w medycynie, m.in. glikozydy sterydowe (nasercowe), witamina $\mathrm{P}$, witamina $\mathrm{B}_{2}$. Właściwości lecznicze preparatów ziołowych często związane są z glikozydowymi połączeniami aglikonów o właściwościach antyseptycznych i bakteriostatycznych. Do takich zalicza się m.in. arbutyna (np. z mącznicy lekarskiej (Arctostaphylos uva-ursi (L.) Spreng.)), salicyna (z wierzby (Salix L.)), synigryna (np. $\mathrm{z}$ chrzanu pospolitego (Armoracia rusticana), czarnej gorczycy (Brassica nigra)). Glikozydy wytwarzane są w organach asymilacyjnych rośliny, a następnie gromadzone w korze, kłączach, korzeniach, owocach i nasionach ${ }^{150}$. Fizjologicznie czynne związki

149 Wielka encyklopedia powszechna PWN. T. 1..., s. 157-158.

150 Farmakognozja. Podręcznik dla studentów farmacji. Red. I. Matławska, Poznań: Akademia Me- 
chemiczne zawarte w roślinie nie są równomiernie rozmieszczone we wszystkich jej częściach. W celach terapeutycznych wykorzystuje się te części roślin, w których występuje najwięcej związków. W kwiatach kasztanowca (Aesculus L.) występują flawonoidy (rutyna, astragalina, kwercytyna, zowercytyna), kumaryny, garbniki, fenolokwasy; kora zawiera flawonoidy, związki kumarynowe, garbniki i saponiny trójterpentynowe (eskulina), w nasionach znajdują się związki kumarynowe, escyna, fenolokwasy, flawonoidy, garbniki, skrobia i cukry. Ponadto zawiera on karotenoidy, witaminę K i sole mineralne. Kasztanowiec jest rośliną wykazującą działanie przeciwzapalne, przeciwbólowe, przeciwbakteryjne, rozkurczające, przeciwkrwotoczne oraz uszczelniające ściany naczyń krwionośnych włoskowatych, zmniejszające kruchość i przywracające elastyczność naczyń krwionośnych, jak również wzmacniająco odporność organizmu. Jest on także rośliną kosmetyczną (działa kojąco i regenerująco na skórę). Stosuje się napar ze świeżych lub suchych liści w celach leczniczych w przypadku żylaków, reumatyzmu, krwawej biegunce, krwiomoczu, zapaleniu nerek, kamicy moczowej, zbyt obfitej menstruacji, krwotokach z nosa, chorobach wątroby. Naparu mieszanki z liści i kwiatu kasztanowca w połączeniu z surowcami innych roślin leczniczych używa się przy zaparciach, żylakach odbytu, niestrawności, zaburzeniach trawienia, biegunkach, chorobie wrzodowej, wzdęciach i otyłości. Korę kasztanowca w połączeniu z surowcami innych ziół stosuje się w miażdżycy.

Surowcem zielarskim bzu czarnego (Sambucus nigra L.) są kwiaty oraz dojrzałe czarne owoce, rzadziej liście i kora ${ }^{151}$. Wszystkie części rośliny zawierają toksyczny składnik - sambunigrynę, który po spożyciu rozkładany jest do cyjanowodoru, który powoduje uczucie słabości i wymioty. Po odpowiednim przetworzeniu następuje jej rozkład. Kwiaty bzu dzikiego zawierają olejki eteryczne, śluzy, związki wapnia, potasu, sodu, glinu i żelaza, glikozydy cyjanogenne, saponiny triterpenowe, flawonoidy (rutynę, kwercetynę, estragalinę), garbniki. Owoce zaś bogate są w witaminy: A, B1, B2, C i J, antocyjany, olejki eteryczne, garbniki, glikozydy cyjanogenne (sambunigrynę), pektyny, kwasy organiczne: octowy, jabłkowy, walerianowy, winowy i benzoesowy. Kwiaty działają moczopędnie (lek stosowany przy kamicy nerkowej), napotnie i przeciwgorączkowo, wzmacniają naczynia krwionośne (uelastyczniają ścianki naczyń włosowatych). Kwiaty też zalecane są na katar, astmę, gorączkę przebiegającą z wysypką, różyczkę, szkarlatynę, stany reumatyczne, zapalenia pęcherza, oskrzeli, gruźlicę, choroby skórne, czyraczność, dolegliwości oczu. Zewnętrznie stosuje się je do przemywania oczu i płukania gardła w stanach zapalnych. Owoce działają przeczyszczająco, moczopędnie, napotnie, przeciwbólowo (np. w rwie kulszowej, zapaleniu nerwu trójdzielnego i bólach neuralgicznych), odtruwająco; stosuje się je w niedomaganiach wątroby, żółtaczce, dyspepsji, nerwicach i nerwobólach. Rdzenia białych młodych gałęzi używa się w artretyzmie, reumatyzmie, dnie moczanowej, puchlinie wodnej, zapaleniach nerek, kamicy moczowej, padaczce. Liście posiadają właściwości moczopędne i napotne, lekko żółciopędnie i rozwalniająco, zwiększają odporność na choroby

dyczna im. Karola Marcinkowskiego, 2005.

151 Zielnik dla każdego, czyli opis ziół wykorzystywanych w leczeniu domowym wraz z praktycznym zastosowaniem (napary, wywary i wyciagi zdrowotne). Oprac. J. Rogala, R. Maciej. Ożarów Mazowiecki: Olesiejuk, 2009. 
zakaźne; stosowane zewnętrznie podwyższają przepuszczalność naczyń włosowatych, zwalczają stany zapalne jamy ustnej i gardła.

Wiele surowców roślinnych wykazuje działanie przeciwzapalne, przeciwbakteryjne, przeciwwirusowe, wzmacniające organizm i immunostymulujące. Wykryto, iż niektóre surowce oferowane przez naturę charakteryzują się właściwościami przeciwnowotworowymi lub przynajmniej zmniejszają niebezpieczeństwo przerzutów ${ }^{152}$. Należy do nich huba brzozowa, a właściwie czyr brzozowy (Inonotus obliquus). Zewnętrznie na guzy, narośle i nowotwory stosuje się liście pokrzywy (Urtica dioica L) i wyciągi z szyszek chmielu (Humulus L.). Bukwica lekarska (czyściec lekarski, Stachys officinalis (L.) Trevis., syn. Betonica officinalis L.) leczy guzy twarde przechodzące w tkankę nowotworową. Świeży sok z bodziszka cuchnącego (Geranium robertianum L.) bywa rekomendowany przeciw rakowatym wrzodom i złośliwym wyrzutom, a pelargonia francuska (Pelargonium-Geranium odorantissimum) wykazuje dużą skuteczność w leczeniu ran i złamań kości, przeciwdziała nowotworom - stosuje się ją również pomocniczo w nowotworach macicy. Przeciwnowotworowe działanie posiadają seskwiterpeny zawarte w lebiodce pospolitej (Origanum vulgare), kwas oleinowy, linolenowy, geraniol, pinen, linalol i limonen zawarte w kolendrze siewnej (Coriandrum sativum L.). Pomocniczo i w połączeniu z innymi lekami podaje się przetwory z kwiatów nagietka lekarskiego (Calendula officinalis L.) w nieoperacyjnych postaciach raka żołądka, stanach przednowotworowych w przewodzie pokarmowym, na przykład w długotrwałym przewlekłym zapaleniu błon śluzowych, owrzodzeniu z krwawieniami, braku poprawy po zastosowaniu innych leków chemicznych. Kwiaty nagietka zawierają olejek eteryczny, flawonoidy, karotenoidy, związki trójterprenowe (saponzydy), tj. arnidiol i faradiol, śluzy, związki żywicowe, gorycze, kwas jabłkowy itd. Potwierdzone naukowo właściwości antynowotworowe posiada czarnuszka siewna (Nigella sativa L., Nigella indica), bogata $\mathrm{w}$ antyoksydanty i fitosterole, m.in. alfa-hederynę. Trwają intensywne badania naukowe zmierzające do wyizolowania z roślin substancji o własnościach przeciwnowotworowych wykorzystywanych w leczeniu biologicznym nowotworów ${ }^{153}$, a także leczenia immunologicznego i immunosupresyjnego. Zwraca się uwagę na stosowanie właściwej diety, która ma istotny wpływ w profilaktyce chorób. Badania kliniczne wykazały, iż dieta bogata w składniki naturalne, roślinne może zmniejszać ryzyko zachorowania na nowotwory. Wynika to z faktu występowania w roślinach naturalnych antyoksydantów, bądź innych specyficznych właściwości związków roślin, takich jak zdolność hamowania procesów angiogenezy oraz stymulowania naturalnych procesów prowadzących do eliminacji komórek nowotworowych, czyli apoptozy ${ }^{154}$.

\footnotetext{
152 T. Książkiewicz. Zioła w walce z nowotworami. Uwierzyć wbrew nadziei. Warszawa: Oficyna Wydawnicza Rytm, 2000.

153 Szerzej o tym: Ł. Świątek. Nadzieja na nowe leki onkologiczne. „Aptekarz Polski” 2009, nr 9 (31). [Online:] <http://www.aptekarzpolski.pl/index.php?option=com_content\&task=view\&id=297\&Itemid=86> (dostęp: 1.07 .2010$)$.

154 Ibidem.
} 


\section{Odkrycie związków przeciwdrobnoustrojowych}

Pierwsze wiadomości na temat „szczepień” prewencyjnych, dotyczących zamierzonego, w celach profilaktycznych, infekowania ospą osób zdrowych pochodzą z Chin z przełomu I i II wieku p.n.e. Metoda ta rozpowszechniła się w XV wieku Chinach, Indiach i Turcji i niegdyś nazwano ją wariolacją. Polegała na przenoszeniu przy pomocy igły wydzieliny ropnej pochodzącej od osób lekko chorych na osoby zdrowe.

Próby zastosowania drobnoustrojów bądź produktów ich metabolizmu do walki $\mathrm{z}$ chorobami podejmowane były już w starożytności. W medycynie ludowej do leczenia ropiejących ran i owrzodzeń stosuje się zazwyczaj produkty spożywcze pokryte zielonkawym nalotem grzybów pleśniowych. W Chinach około 3000 lat p.n.e. medycy w zakażeniach stosowali okłady z przefermentowanej mączki sojowej, a w egipskim papirusie Ebersa jest mowa o zaletach okładów z „drożdży słodkiego piwa” na źle gorące się rany. Mikroorganizmy znane były ze swych własności przeciwzapalnych u cywilizowanych prekolumbijskich ludów indiańskich - Majowie i Inkowie hodowali grzyby pleśniowe na prażonej kukurydzy w celach leczniczych. Pleśń do leczenia ran stosowali też Indianie północnoamerykańscy. Na przestrzeni XIX wieku prowadzono badania w zakresie zastosowań mikroorganizmów wytwarzających antybiotyki. Już pod koniec XIX wieku uczeni byli o krok od pozyskania antybiotyku skutecznego $\mathrm{w}$ walce z zarazkami.

Bakterie jako pierwszy zidentyfikował w 1670 roku Antoni van Leeuwenhoek dzięki wynalezieniu mikroskopu ${ }^{155}$. Jednak do XIX wieku nie doceniano ich związku $\mathrm{z}$ chorobami. Przełom nastąpił dopiero w badaniach Louisa Pasteura - nowoczesna era walki z chorobami infekcyjnymi rozpoczęła się $\mathrm{w}$ momencie, gdy udało mu się udowodnić rolę drobnoustrojów w procesie infekcji ${ }^{156}$. Pasteur wykazał bakteryjny charakter choroby dziesiątkującej hodowle jedwabników oraz opracował metody pozwalające na ich hodowlę wolną od bakterii. Istotny wkład do wiedzy na temat możliwości zastosowań związków chemicznych w praktyce medycznej wniósł w pierwszej połowie XIX wieku węgierski lekarz położnik Ignaz Philipp Semmelweis ${ }^{157}$. Jego zasługą jest wyeliminowanie ze szpitali położniczych gorączki połogowej. Semmelweis był wielkim rzecznikiem higieny i aseptyki w szpitalnictwie, odkażania rąk przez lekarzy, częstej dezynfekcji pościeli i ubioru szpitalnego ${ }^{158}$.

Odkrycie przez Pasteura etiologii chorób zakaźnych dało początek badaniom nad wpływem różnego typu substancji chemicznych na drobnoustroje chorobotwórcze. Ich nadrzędnym celem było poszukiwanie optymalnie działającego związku chemicznego do dezynfekcji. Odkryto m.in., że woda utleniona w stężeniu 1-2 \% zabija drobnoustroje ropiejących ran, szczególnie gronkowce i paciorkowce. Kwas salicylowy i benzoesowy stosowane są do konserwacji produktów spożywczych - hamują także rozwój grzybów chorobotwórczych (pleśni). Zauważono też, iż kwas benzoesowy wy-

155 P. Graham, Chemia medyczna. Podstawowe zagadnienia. Przeł. E. Mikiciuk-Olasik. Warszawa: Wydawnictwa Naukowo-Techniczne, 2003, s. 41.

156 S. Russell. Antybiotyki..., s. 12.

157 Ibidem, s. 15.

158 Ibidem, s. 15. 
stępuje w dużych ilościach w owocach roślin runa leśnego, czym tłumaczy się lecznicze właściwości jagód w schorzeniach przewodu pokarmowego (wyciągi z jagód były podstawowym środkiem terapeutycznym w medycynie ludowej) ${ }^{159}$. Ogólnie można stwierdzić, iż wykrycie śmiertelnych własności niektórych związków chemicznych dla mikroorganizmów chorobotwórczych stało się podstawą rozwoju antyseptyki i aseptyki, co przyczyniło się przede wszystkim do wyeliminowania licznych powikłań pooperacyjnych powstających $\mathrm{w}$ wyniku zakażenia ran mikroorganizmami ropotwórczymi.

Pierwszym antybiotykiem ${ }^{160}$ była penicylina odkryta przez Aleksandra Fleminga w 1928 roku. Przeglądając pożywki, na których rozwijały się bakterie, zauważył on, iż przypadkowe zanieczyszczenie podłoża pleśnią Penicillium notatum powstrzymuje wzrost kultur bakterii Staphylococcus aureus. Wyniki swych badań Fleming opublikował od razu, jednak do 1940 roku w świecie medycznym panowała cisza. Dopiero w 1940 roku Florey i Chain wyizolowali penicylinę w czystej postaci. Lek ten zrewolucjonizował walkę z infekcjami bakteryjnymi i okazał się dużo skuteczniejszy od sulfonamidów. W czasie wojny właśnie penicylina wraz z konserwowaną krwią przyczyniła się do zwycięstwa aliantów (żołnierze mieli już świadomość, że istnieją leki, które mogą uratować im życie) ${ }^{161}$.

Potrzebne były jednak nowe leki przeciwbakteryjne, bowiem penicyliny nie były skuteczne w leczeniu wszystkich rodzajów zakażeń. Penicylina jest substancją wytwarzaną przez grzyby w celu zabicia bakterii mogących współzawodniczyć o pożywienie. Uświadomiwszy sobie fakt, iż grzyby mogą stać się źródłem nowych antybiotyków, uczeni na szeroką skalę przystąpili do badań nad nieznanymi kulturami mikrobów. Wcześniej w 1939 roku francuski mikrobiolog René Dubos podłożył podwaliny pod współczesną naukę o antybiotykach, dokonując szeregu istotnych odkryć z dziedziny mikrobiologii gleby. Do hodowli zjadliwych pałeczek riketsji (powodujących dur brzuszny) dodał szczepy bakterii wyizolowane z gleby. Dubos odkrył, że drobnoustroje izolowane z gleby hamują wzrost sprawców duru brzusznego, a szczególnie silnym antagonistą wobec riketsji jest bakteria Bacillus brevis. W 1939 roku doświadczenia Dubosa zwieńczone zostały wyizolowaniem pierwszego znanego antybiotyku - tyrotrycyny. Badania organizmów występujących w glebie przyczyniły się do odkrycia w 1944 roku przez urodzonego na Ukrainie mikrobiologa Selmana Waksmana - pierwszego antybiotyku aminoglikozydowego - streptomycyny. Możliwe stało się zwalczanie pałeczek gruźlicy i różnych bakterii Gram-ujemnych. Waksman w późniejszym czasie odkrył zresztą jeszcze inny antybiotyk pochodzenia promieniowcowego - neomycynę.

Po zakończeniu II wojny światowej uzyskano antybiotyki peptydowe (m.in. bacytracynę), chloramfenikol, antybiotyki tetracyklinowe, makrolidowe, cykliczne peptydowe antybiotyki, a w 1955 roku pierwszy antybiotyk z drugiej grupy $\beta$-laktamowych - cefalosporynę C. Prekursory cefalosporyn wyizolował po raz pierwszy z hodowli grzyba Cephalosporium acremonium w 1948 roku włoski naukowiec z Sardynii Giuseppe Brotzu.

\footnotetext{
159 Ibidem, s. 15.

160 Ibidem, s. 26-31.

161 Ibidem, s. 26-31.
} 
Od czasu odkrycia pierwszych antybiotyków i innych chemoterapeutyków ziołolecznictwo zaczęto traktować jako przejaw zacofania, czarów i zabobonów. Wielkie nadzieje pokładano w najnowocześniejszych syntetycznych preparatach farmaceutycznych często nie mając świadomości ich poważnych skutków ubocznych.

\section{Odkrycie witamin}

W latach osiemdziesiątych XIX wieku Michaił Łunin stwierdził, iż do właściwego rozwoju zwierząt niezbędne są substancje chemiczne inne niż poznane dotychczas białka, tłuszcze, węglowodany i sole mineralne ${ }^{162}$. W 1897 roku po raz pierwszy opisano chorobę beri-beri, nękającą osoby odżywiające się głównie łuskanym ryżem. Poprawa stanu ich zdrowia następowała po włączeniu do diety otrąb ryżowych. W 1911 roku wyizolowano substancję chroniącą przed zachorowaniem na beri-beri - aminę życia (tj. witaminę). W niedługim czasie odkryto również istnienie witamin rozpuszczalnych w tłuszczach, m.in. witaminy A, których niedobór powoduje zahamowanie wzrostu oraz zaburzenia widzenia. Następnie z tranu wyizolowano witaminę D zapobiegającą krzywicy.

W latach trzydziestych XX wieku poznano przyczynę szkorbutu - wyodrębniono witaminę $C$. W latach 20 . wydzielono witaminę $B_{1}$ - aneurynę (tj. tiaminę), $B_{2}$ (ryboflawinę), a później $\mathrm{B}_{6}$ (pirydoksynę) i $\mathrm{B}_{12}$ (kobalaminę), amid kwasu nikotynowego - witaminę PP, opisano witaminę $\mathrm{H}$ niezbędną do utrzymania prawidłowego rozwoju skóry (wcześniej z żółtka jaja kurzego wyizolowano biotynę). W 1929 roku duński uczony Henrik Dam zaobserwował, iż kurczęta pozbawione tłuszczu mają zaburzenia krzepliwości krwi - czynnik występujący w tłuszczu wieprzowym nazwał witaminą K.

Rośliny posiadają swój tajemniczy skład chemiczny ${ }^{163}$. Są skarbnicą wielu cennych substancji. Do najpopularniejszych roślin bogatych w witaminy i minerały zalicza się m.in. różę dziką (Rosa canina) (zawiera mnóstwo witaminy $\mathrm{C}$, a także $\mathrm{E}, \mathrm{K}, \mathrm{PP}$, witaminy z grupy B, prowitaminę A), pokrzywę zwyczajną (Urtica dioica L.) (odnajdziemy $\mathrm{w}$ niej rozpuszczalne $\mathrm{w}$ tłuszczach witaminy $\mathrm{A}, \mathrm{E}$ i K, ponadto witaminy z grupy $\mathrm{B}$, witaminę PP oraz C), skrzyp polny (Equisetum arvense) itd. Lecznicze działanie wykazują nawet niektóre rośliny doniczkowe, na przykład drogocenny aloes (Aloë L.).

\section{Chemioterapia nowotworów}

Współcześnie naukowcy odkrywają właściwości roślin, zdolnych pokonywać komórki nowotworowe ${ }^{164}$. W 1962 roku amerykański botanik Arthur Barclay stwierdził terapeutyczne działanie wyciągu z kory trujących cisów kalifornijskich drzew ${ }^{165}$.

162 Por. S. Aldride. Magiczne cząsteczki. Jak działają leki. Przeł. B. Paluchowska. Poznań: Dom Wydawniczy „Rebis”, 2001, s. 315; K. Rożnowska. Witaminy i biopierwiastki. Kraków: Agencja Wydawniczo-Usługowa „Emilia”, 1997.

163 Zob. P. Czikow, J. Łaptiew. Rośliny lecznicze i bogate w witaminy. Z ros. przeł. H. Terpińska-Ostrowska. Wyd. 4. Warszawa: Państwowe Wydaw. Rolnicze i Leśne, 1988.

164 O tym: Onkologia. Podręcznik dla lekarzy i studentów. Red. R. Kordek. Gdańsk: ViaMedica, 2006.

165 Ł. Kaniewski. Lek z kory trującego drzewa. „Medycyna i Zdrowie” 21.03.2016. [Online:] <http:// 
Wyizolowana z kory drzew substancja czynna paklitaksel (od łac. Taxus 'cis') weszła w skład nowego leku na raka trzustki ${ }^{166}$. Cisy fascynowały ludzi od tysiącleci. Z ich twardego drewna wykonywano broń (włócznie, łuki), zdawano sobie również sprawę z jego toksyczności. Dzięki swoim wiecznie zielonym igłom cis uchodził za symbol życia i odrodzenia.

W latach 80. odkryto lecznicze działanie winorelbiny - alkaloidu wyizolowanego $\mathrm{z}$ barwinka różowego (Catharantus roseus), pochodzącego z Madagaskaru. Roślina ta zawiera też winkrystynę. Obydwa alkaloidy mają zastosowanie jako cytostatyki w leczeniu szeregu chorób nowotworowych. Zdarza się, że roślina ta jest mylona z innym gatunkiem barwinka, któremu również przypisuje się działanie przeciwnowotworowe - Vinca cora ${ }^{167}$.

Aloes (Alö̈ L.), którego mięsiste liście zawierają mnóstwo substancji aktywnych, takich jak m.in. aloina, barbaloina, aloeemodyna, wykorzystywany jest do produkcji leków wspomagających leczenie nowotworów (powstrzymuje m.in. rozwój białaczki).

Przykłady dobroczynnych właściwości terapeutycznych roślin można by było mnożyć.

\section{Toksyczne działanie leków roślinnych}

\section{Skutki uboczne fitoterapii}

Znakomita większość leków roślinnych w opinii powszechnej uważana jest za bezpieczną w stosowaniu. Zwolennicy fitoterapii przedstawiają zwykle działania uboczne leków roślinnych jako mało szkodliwe, natomiast jej przeciwnicy odrzucają fitoterapeutyki jako środki mało skuteczne i częściowo negują niebezpieczeństwo związane $\mathrm{z}$ ich użyciem. W piśmiennictwie medycznym wymienia się pewne skutki uboczne fitoterapii ${ }^{168}$ : 1) reakcje alergiczne, 2) efekty toksyczne, 3) niezamierzone działanie farmakologiczne, 4) działania mutagenne, karcinogenne, 5) interakcje z innymi lekami, 6) skutki spowodowane kontaminacją (zanieczyszczenie, skażenie), 7) następstwa błędnej identyfikacji surowców. Trzeba podkreślić, iż reakcja alergiczna może być w istocie skutkiem użycia każdego rodzaju ekstraktu roślinnego. Alergie występują częściej i są bardziej nasilone w przypadku, gdy poprzedza je reakcja uczuleniowa. Na ogół aplikacje parenteralne są dużo bardziej niebezpieczne niż dawki doustne. Nie tak dawno w literaturze medycznej doniesiono o wystąpieniu reakcji anafilaktycznej po użyciu preparatu Echinacea ${ }^{169}$. Oczywiste jest, iż część roślin jest toksyczna; zawie-

www.rp.pl/Medycyna-i-zdrowie/303219873-Lek-z-kory-trujacego-drzewa.html\#ap-2> (dostęp: 8.02.2017).

166 Zob. Paclitaxel-Ebewe (paklitaksel) - koncentrat do sporządzania roztworu do infuzji. [W:] Bazaleków. [Online:] <https://bazalekow.mp.pl/lek/63208,Paclitaxel-Ebewe-koncentrat-do-sporzadzaniaroztworu-do-infuzji> (dostęp: 2.08.2017).

167 Ibidem.

168 B. Czerny. Uwagi na temat ubocznych efektów stosowania roślinnych środków leczniczych. „Postępy fitoterapii" 2000, nr 3, s. 21. [Online:] <http://www.czytelniamedyczna.pl/postepy_fitoterapii-67> (dostęp 11.06.2010).

169 Ibidem, s. 21 
rają one związki o bardzo silnym działaniu fizjologicznym, będące niekiedy trucizną. Dlatego stosowanie wielu preparatów ziołowych winno odbywać się: 1) po konsultacji z lekarzem w ściśle uzgodnionej dawce (na przykład przetwory z brzozy, chmielu), 2) leki należy nabywać jedynie w miejscach do tego upoważnionych (apteki i licencjonowane sklepy zielarskie). Trzeba też mieć na względzie to, iż zwiększone stężenie niektórych substancji uważanych za bezpieczne może wywołać niepożądane objawy. Do toksycznie działających związków należą $\left.{ }^{170}: 1\right)$ alkaloidy tropinowe z liści pokrzyku wilczej jagody (Atropa belladonna L.), bielunia (Datura L.) i lulka (Hyoscyamus L.), 2) alkaloidy z opium lub z makówek, np. morfina, kodeina, papaweryna, 3) alkaloidy ze sporyszu (Secale cornutum), na przykład ergotamina, ergotoksyna, ergometryna, 4) ardenolidy z liści naparstnicy (Digitalis L.), ziela konwalii (Convallaria L.), ziela miłka wiosennego (Adonis vernalis L.), cebuli morskiej (urginia morska, Drimia maritima) i nasion strofantu (skrętnika, Strophanthus), 5) efedryna z ziela stroiczki (Lobelia), 6) kolchicyna $z$ nasion i cebuli ziwowitu (Colchicum), 7) rezerpina i ajmalina z korzeni rauwolfii żmijowej (Rauvolfia serpentina), 8) strychnina $\mathrm{z}$ nasion kulczyby wroniego oka (Strychnos nux-vomica L.), 9) akonityna $\mathrm{z}$ bulw tojadu (Aconitum L.), 10) chinina $z$ kory chinowej (Cinchona L.).

W surowcach roślinnych zwykle znajduje się cały kompleks alkaloidów. Niektóre $\mathrm{z}$ nich wykazują bardzo silne działanie prowadzące do zgonu. Wiele toksycznych alkaloidów podawanych w małych dawkach leczniczych stanowi skuteczne leki, na przykład morfina, kodeina, chinina, efedryna; liczne alkaloidy są składnikami używek, na przykład kofeina, teobromina, nikotyna. Zawarta w chmielu lupulina stosowana w zbyt dużej ilości może okazać się niebezpieczna. Przeciwwskazane jest zażywanie glistnika jaskółczego ziela (Chelidonium majus L.) oraz leków, których składnikiem jest atropina i jej podobne (z uwagi na właściwości lekko narkotyczne), w przypadku kobiet w ciąży, dzieci, osób cierpiących na zaćmę czy jaskrę ${ }^{171}$. Przedawkowanie kopytnika (Asarum europaeum L.) jest bardzo niebezpieczne i skutkuje nudnościami, wymiotami, podrażnieniem przewodu pokarmowego i nerek, zapaścią, drgawkami, halucynacjami i majaczeniem. Bylica piołun (Artemisia absinthium L.) zawiera spore ilości tujonu - związku silnie toksycznego, dlatego napary z ziela powinny być stosowane rzadko i w niewielkich ilościach, gdyż mogą powodować agresywność, bóle i zawroty głowy. Szereg przeciwwskazań wiąże się z rdestem ptasim (świńską trawą, Polygonum aviculare L.), którego nie wolno zażywać przy uczuleniach na promienie słoneczne, po zawale, przy zatorach, dusznicy bolesnej, zapaleniu żył, postrzałach, kręczu szyi, skłonności do tycia, otyłości, opryszczkach, cukrzycy, półpaścu. Toksyczne alkaloidy, na przykład strychninę, wykorzystuje się do zwalczania szkodników. Do niezwykle silnych trucizn należy tubokuraryna występująca w Chondodendron tomentosum. Używana ona była do zatruwania grotów strzał przez Indian południowoamerykańskich. Efekty toksyczne stosowania fitoterapeutyków na ogół dotyczą wątroby. Możliwe są także uszkodzenia toksyczne innych narządów: nerek, mięśnia sercowego. Spośród potencjalnych działań niepożądanych tego typu wymienia się efekty toksyczne spowodowane na przykład używaniem kory korzenia Sassafras w leczeniu schorzeń reuma-

\footnotetext{
170 Ibidem, s. 21.

171 Zielnik dla każdego..., s. 51.
} 
tycznych, żywokostu lekarskiego (Symphytum officinale L.) jako środka przeciwzapalnego, pennyroyali (np. mięta polej, Mentha pulegium L.) jako środka wiatropędnego. Surowce, które zawierają kwas aristolochiowy, mogą być nefrotoksyczne. Bardzo niebezpieczne może okazać się stosowanie leków pochodzenia azjatyckiego ${ }^{172}$.

Leki roślinne mogą wywoływać również tzw. nieoczekiwane efekty farmakologiczne. Istnieją przeciwwskazania odnośnie stosowania niektórych fitoterapeutyków, takich jak Cimincifuga, Ginseng, Sebal sernilata, które wykazują aktywność estrogenową, lucerna (Medicago L.), biedrzeniec anyż (Pimpinella anisum L.), arnika (Arnica L.), czarcie łajno (smrodzieniec, asafetyda) ${ }^{173}$, miłorząb (Ginkgo biloba L.), rumianek (Matricaria chamomilla L.), czosnek (Allium sativum L.) wpływające na parametry krzepnięcia krwi ${ }^{174}$. Rezultatem interakcji leków może być wzmocnienie bądź osłabienie działania leku, a także skrócenie lub wydłużenie czasu jego działania ${ }^{175}$. Przykładowo preparaty z czosnku pospolitego (Allium sativum L. $)^{176}$ powodują wzrost aktywności warfaryny ${ }^{177}$, co wskutek zmniejszenia agregacji płytek krwi grozi krwotokami pooperacyjnymi. Preparaty z miłorząbu dwuklapowego (Ginkgo biloba) w połączeniu $\mathrm{z}$ aspiryną mogą powodować krwiaki przedniej komory oka, a w połączeniu z paracetamolem - krwiaki ponadtwardówkowe. Preparaty z popularnego żeń-szenia (ginseng, wszechlek, Panax ginseng C.A. Meyer) wraz z fenelzyną wywołują bóle głowy, drżenie i stany maniakalne, a preparaty z lukrecji (Glycyrrhiza L.) - podwyższenie poziomu prednizolonu w surowicy krwi. Z kolei preparaty z babki jajowatej (Plantago ovata) obniżają poziom litu we krwi. Preparaty z dziurawca (Hypericum perforatum L.) mogą wraz $\mathrm{z}$ sertraliną spowodować objawy serotoninowe, a aplikowane równocześnie z cyklosporyną obniżają jej poziom w surowicy, co grozi odrzuceniem przeszczepu $^{178}$. Niebezpieczna w skutkach może być efedryna, której nie zaleca się niemowlętom, kobietom ciężarnym i karmiącym (powoduje spadek ciśnienia u płodu i niemowląt). Efedryna wchodzi także w interakcje z niektórymi lekami, m.in. ze środkami używanymi w kardiologii, na przykład z beta-adrenolitykami, inhibitorami MAO, metylodopą, kofeiną i teofiliną. Równoczesne podawanie efedryny z kofeiną powoduje oporność na insulinę oraz hipokaliemię, może doprowadzić do wzrostu częstotliwości skurczów serca i podwyższenia ciśnienia tętniczego, arytmii, dyslipidemii oraz cukrzycy typu $\mathrm{II}^{179}$.

\footnotetext{
172 B. Czerny. Uwagi na temat ubocznych efektów stosowania...

173 Gumożywica otrzymywana z korzeni i kłączy zapaliczki cuchnącej (Ferula assa-foetida).

174 Ibidem.

$175 \mathrm{~K}$. Blecharz-Klin et al. Interakcje leków roślinnych stosowanych w chorobach układu oddechowego. „Herba Polonica” 2005, nr 3-4 (51), s. 89-97.

176 Podawanie osobom zakażonym wirusem HIV wyciągu z czosnku powoduje nieznaczne zmniejszenie AU C dla inhibitora proteazy HIV-1 - ritonawiru. U chorych tych zażywających czosnek w połączeniu z lekami przeciwwirusowymi zaobserwowano działanie toksyczne skutkujące zaburzeniami funkcji układu pokarmowego. Zob. K. Blecharz-Klin et al. Interakcje leków roślinnych stosowanych..., s. 89-97.

177 Ibidem.

178 B. Kędzia, J. Alkiewicz. Interakcje pomiędzy lekami roślinnymi stosowanymi w inhalacjach a lekami syntetycznymi stosowanymi doustnie. „Postępy fitoterapii” 2006, nr 2, s. 105.

179 K. Blecharz-Klin et al. Interakcje leków roślinnych stosowanych..., s. 89-97.
} 


\section{Olejki eteryczne}

Olejki eteryczne wykorzystywane są w aromaterapii, inhalacjach leczniczych i odkażaniu pomieszczeń. W przypadku nadwrażliwości osobniczej mogą one wywoływać pewne działania alergizujące, co dotyczy zwłaszcza dzieci i młodzieży. Mogą ponadto spowodować alergię wziewną, kontaktową oraz odczyny toksyczne w następstwie zetknięcia się skóry z pewnymi substancjami ziołowymi. Zmiany skórne powstałe na skutek kontaktu z alergenem mają charakter wyprysku bądź zapalno-obrzękowe (odczyn pęcherzowy); towarzyszy im świąd, następuje wtórne zakażenie bakteryjne. Alergię może powodować bezpośrednio dotknięcie świeżych roślin, na przykład pierwiosnków, ruty, bylicy, sumaku, komosy, złocienia, jak również kontakt z substancjami zawartymi w olejku eterycznym drogą wziewną. Praktycznie każdy typ olejku lotnego może wywoływać podrażnienia śluzówki górnych i dolnych dróg oddechowych, skutkujące skurczem krtani lub oskrzeli, a nawet wywołać ataki astmy. Szczególnie osobami wrażliwymi na surowce zielarskie są pacjenci cierpiący na pyłkowicę. Za lek bezpieczny uważa się miętę pieprzową zalecaną nawet małych dzieciom, jednak większe ilości olejku otrzymywanego z liści mięty pieprzowej, zawierającego mentol, menton, izomenton, 1,8-cyneol są toksyczne i mogą wywołać nie tylko alergię objawiającą się kurczem krtani, oskrzeli, ale i poważniejsze zatrucie (wymioty, zaburzenia równowagi, senność). Olejek miętowy wywołuje także interakcje z innymi lekami powodując wzrost toksyczności glikozydów nasercowych, hamując aktywność enzymu wątrobowego metabolizującego leki CYP 3A4 (cyklosporyna, lowastatyna, ketokonazol, triazolam $)^{180}$. W interakcje $\mathrm{z}$ innymi lekami syntetycznymi, a także roślinnymi, wchodzą olejki stosowane tradycyjnie w schorzeniach zapalnych górnych dróg oddechowych, takie jak anyż (Pimpinella anisum L.) czy eukaliptus (Eucalyptus L'Hér.). W anyżu aktywnym składnikiem jest anetol pobudzający aktywność nabłonka rzęskowego w oskrzelach. Anetol wchodzi jednak w reakcję krzyżową z koprem włoskim (Foeniculum vulgare Mill.), drzewem kamforowym (Cinnamomum camphora Ness et Eberm.), kminkiem (Carum L.) i kolendrą (Coriandrum L.) ${ }^{181}$. Główny składnik olejku anyżowego otrzymywanego z owoców - trans-anetol obniża działanie leków przeciwzakrzepowych, przeciwlękowych i podwyższających ciśnienie. Olejek z owoców kopru włoskiego, zawierający trans-anetol i fenchon, wzmaga działanie leków przeciwepileptycznych (fenobabital), obniża działanie antybiotyku ciprofloksacyny, inhibitor konwertazy angiotensynowej (zmniejsza działanie enalaprilu - leku obniżającego ciśnienie tętnicze $)^{182}$. Fenchol - składnik kopru włoskiego, wywiera działanie drgawkotwórcze, dlatego stosowany u dzieci stanowić może zagrożenie dla osób o obniżonym progu drgawkowym. Podobne zagrożenie mogą nieść ze sobą inne produkty fitoterapuetyczne zawierające olejki z monoterpenowymi ketonami, tj. kamforą, pinokamfonem, tujonem, cyneolem i pulegonem ${ }^{183}$. Istnieją przeciwwskazania do stosowania popularnego olejku lawendowego (Oleum Lavandulae), m.in. w ostrych

\footnotetext{
180 B. Kędzia, J. Alkiewicz. Interakcje pomiędzy lekami roślinnymi..., s. 105.

$181 \mathrm{~K}$. Blecharz-Klin et al. Interakcje leków roślinnych stosowanych $w$ chorobach układu oddechowego...

182 B. Kędzia, J. Alkiewicz. Interakcje pomiędzy lekami roślinnymi..., s. 105.

183 K. Blecharz-Klin et al. Interakcje leków roślinnych stosowanych..., s. 89.
} 
i podostrych zapaleniach żołądka, jelit, wyrostka robaczkowego, a także w chorobie wrzodowej, w przypadkach krwawienia z przewodu pokarmowego i poważnych schorzeń wątroby i nerek. Leki zawierające olejek kopytnikowy są zabronione dla kobiet ciężarnych z uwagi na właściwości poronne, z kolei azaron (trans-izoazaron) zawarty w kopytniku pospolitym (Asarum europaeum L.) ma także działanie karcynogenne.

Znamienne, iż zwierzęta omijają rośliny o działaniu toksycznym.

\section{Antrazwiązki}

Antrazwiązki stanowią pochodne antracenu i wykazują fizjologiczne działanie przeczyszczające głównie w jelicie grubym. Wskutek zażycia zbyt dużych dawek antrazwiązków dochodzi do przekrwienia błony śluzowej jelita, przede wszystkim odbytnicy, a także narządów miednicy małej (groźba poronienia). Może nastąpić krwawienie z jelit w wyniku uszkodzenia naczyń, istnieje przy tym ryzyko pojawienia się zakażeń infekcyjnych i owrzodzeń. Zaburza to system trawienny, powoduje przekrwienie i podrażnienie nerek, zaś przewlekły stan zapalny oraz przekrwienie może prowadzić do tzw. stanu przedrakowego ${ }^{184}$. Dla toksykologii ważny jest również czas, jaki upłynął od chwili zażycia leku przeczyszczającego do momentu wypróżnienia. Do najbezpieczniejszych zalicza się liście senesu, które działają już po 6-8 godzinach i które w niewielkich dawkach mogą być przyjmowane przez dzieci i ciężarne. Niekorzystne objawy wywołuje natomiast Aloe - stężały sok z aloesu zawarty m.in. w popularnym preparacie Alax ${ }^{185}$. Większe niż lecznicze dawki preparatu aloesu mogą spowodować ogólne osłabienie, spowolnienie pulsu, obniżenie ciepłoty ciała (hipotermia), a przy spożyciu $8 \mathrm{~g}$ proszku - zgon. Antagonistami aloesu są środki narkotyczne i kwasy. Niezgodność wywołują garbniki, żelazo, jod, mentol, tymol, fenol i in. Dlatego przeciwwskazane jest ich równoczesne stosowanie.

\section{Związki antytiaminowe}

W surowcach roślinnych zawarte są dwa rodzaje związków unieczynniające tiaminę (witaminę $B_{1}$ ): 1) związki o aktywności enzymu tiaminazy, 2) czynniki przeciwtiaminowe odporne na temperaturę. Tiaminaza jest enzymem występującym w organizmie ludzkim, który eliminuje aktywność witaminy w wyniku rozszczepienia jej cząsteczki na składniki podstawowe. Mechanizm działania związków drugiej grupy nie został jeszcze dobrze zbadany ${ }^{186}$. Zidentyfikowano kilka związków o właściwościach antwitaminy $\mathrm{B}_{1}$. Odkryto także, że aktywność przeciwwitaminową $\mathrm{B}_{1}$ posiadają niektóre grzyby, przyprawy kuchenne, m.in. cebula (Allium), owoce, na przykład mango indyjskie (Mangifera indica L.), ananasy jadalne (Ananas comosus (L.) Merr.), niektóre odmiany jabłek, a wśród surowców ziołowych - ziele skrzypu polnego (Equisetum arvense), rdestu ptasiego (Polygonum aviculare L.), owoc kolendry (Coriandri fructus), czosnek zwyczajny (Allium sativum L.), prawdopodobnie liście jeżyny (Folium Rubi fruticosi), maliny (Folium Rubi idaei), ziele cząbru ogrodowego (Herba Saturejae). Związki antytiaminowe wykazują odporność na działanie temperatury, pozostają

\footnotetext{
184 Ziołolecznictwo. [W:] Encyklopedia zdrowia. T. 1..., s. 491.

185 Ibidem, s. 492.

186 Ibidem, s. 492.
} 
w odwarach i naparach. Preparaty z tych surowców zażywane w niewielkich dawkach i od czasu do czasu nie wywołają objawów ubocznych, jakim jest ubytek witaminy $\mathrm{B}_{1}$ W przypadku przedłużających się intensywnych kuracji - wielomiesięcznych czy nawet kilkuletnich przy pomocy wyciągów wodnych z tych roślin, np. z ziela skrzypu jako leku moczopędnego, może doprowadzić do znacznego obniżenia w organizmie poziomu witaminy $B_{1}$. Witamina $B_{1}$ jest organizmowi bardzo potrzebna - wspomaga wzrost, uczestniczy w przyswajaniu, zwłaszcza węglowodanów (zamiana glukozy na energię), reguluje procesy metaboliczne, poprawia sprawność umysłu i ogólny nastrój, działa korzystnie na pracę serca i układ mięśniowy, a ponadto zwalcza półpasiec oraz chorobę lokomocyjną i morską. Chorobą wynikającą z niedoboru tej witaminy jest beri-beri - objawiająca się porażeniem mięśni, obrzękami i zaburzeniami pracy nerek ${ }^{187}$.

\section{Związki fotodynamiczne}

W organizmie ludzkim znajduje się hematoporfiryna powodująca, że pod wpływem naświetlającego działania na skórę promieniami nadfioletowymi o długości fal w granicach 297-408 nm, emitowanymi wraz ze światłem słonecznym, skóra przybiera brunatną barwę $e^{188}$. W przypadku zbyt długiego naświetlania pojawia się rumień bądź oparzenie w zależności od wrażliwości osobniczej. W niektórych roślinach występują związki o podobnych do hematoporfiryny właściwościach, a mianowicie: hyperycyna i jej analogi oraz furanokumaryny. Hyperycyna znajduje się w zielu, soku i wyciągu alkoholowym z dziurawca. Przy pomocy leków sporządzanych na bazie dziurawca posiadającego własności fotodynamiczne leczy się bielactwo (smarowania). Zażycie zbyt dużych dawek soku dziurawcowego pod wpływem ekspozycji słonecznej bądź naświetleń lampą kwarcową prowadzi do rumienia i oparzeń, a nawet udaru, który skutkuje hemolizą czerwonych krwinek, krwotokami wewnętrznymi i anemizacją jelit. Związki zbliżone do hyperycyny zawarte są też w zielu gryki - fagopyryna, w niektórych gatunkach Penicillinum - peniciliopsyna ${ }^{189}$. Furanokumaryny wykryto w takich surowcach zielarskich, jak korzeń arcydzięgla litwor (Angelicae Archangelicae radix), biedrzeńca (Radix Pimpinellae) i lubczyka (Levistici radix), liść ruty (Folium Rutae), owoce pietruszki (Fructus Petroselini) i aminka większego (Fructus Ammi majoris), seler zwyczajny (Apium graveolens L.), pasternak zwyczajny (Pastinaca sativa L.) itd. Do najważniejszych furanokumaryn zalicza się: psoralen, ksantotoksynę, bergapten, angelicynę, oksypeucedaninę. Preparatów zawierających furanokumaryny oraz izolowane wyciągi z nich używa się w leczeniu chorób skóry, takich jak bielactwo i łuszczyca. Przedawkowanie tych preparatów połączone z ekspozycją słoneczną lub naświetleniami lampą kwarcową powoduje jednak poważne objawy toksyczne: ogólne osłabienie, bezsenność, bóle i zawroty głowy, nudności i wymioty, a także uszkodzenia wątroby, stany zapalne żołądka i trzustki. Do objawów miejscowych należą: odczyn rumieniowy, rumieniowo-obrzękowy, wypryskowy, wypryskowo-pęcherzowy. Toksykolodzy wykazali także cytotoksyczne działanie furanokumaryn polegające na uszko-

187 K. Rożnowska. Witaminy i biopierwiastki. Przewodnik. Wyd. 2. Kraków: Agencja Wydawniczo-Usługowa „Emilia”, 1997, s. 14.

188 Ziołolecznictwo. [W:] Encyklopedia zdrowia. T. 1..., s. 492.

189

Ibidem, s. 492. 
dzeniu jądra komórkowego i aglutynacji chromosomów ${ }^{190}$. Działanie fotouczulające posiadają również kmin rzymski (Cuminum cyminum L.) i kolendra siewna (Coriandrum sativum L.).

\section{Związki izosiarkocyjanianowe}

W komórkach niektórych roślin leczniczych występują glukozynolaty (glukozydy gorczyczne) - glikozydy zawierające atom siarki ${ }^{191}$. Pod wpływem enzymu mirozynazy, który znajduje się w odrębnych komórkach rośliny macierzystej, glukozynolaty ulegają hydrolizie uwalniając izosiarkocyjaniany. Za najbardziej aktywny uznaje się izosiarkocyjanian allilu (olejek gorczyczny), który znajduje się w nasieniu gorczycy czarnej (Brassica nigra), korzeniu rzodkwi (rzepy) czarnej (Radix Raphani) i korzeniu chrzanu (Radix Armoraciae). Po roztarciu powyższe surowce stosowane są zewnętrznie jako okłady rumieniące (plastry) w bólach reumatycznych, a olejek gorczyczny wchodzi w skład maści, balsamów, mazideł. Zbyt długie działanie preparatu na skórę wywołuje silny piekący ból, ostry stan zapalny z odczynem pęcherzowo-krwotocznym oraz martwicę naskórka, czemu towarzyszą wtórne powikłania bakteryjne. Nadmierne spożywanie tych surowców jako przypraw (np. musztardy) prowadzi do uszkodzeń nerek z krwiomoczem i białkomoczem, a także przekrwienia macicy ${ }^{192}$. Glukozynolany zawarte w nasionach rzepaku (Brassica napus L. var. napus) i kapusty (Brassica L.) hamują natomiast proces utleniania jodków lub jodu, co skutkuje upośledzeniem czynności gruczołu tarczowego i powstaniem wola. Bezpośredni kontakt skóry z miazgą czosnku może wywoływać stan zapalny z trudno gojącymi się wrzodami i nadżerkami.

\section{Glikozydy fenolowe}

Glikozydy w rodzaju arbutyny i metyloarbutyny znajdują się w liściach mącznicy lekarskiej (Folium Uvae-ursi), borówki brusznicy (Folium Vitis idaeae), borówki czarnej (Folium Myrtilli), w korze gruszy (Pyrus communis L.) itd. Są one składnikiem mieszanek ziołowych o działaniu moczopędnym i odkażającym drogi moczowe (arbutyna hydrolizuje w moczu o odczynie alkalicznym i powoduje uwolnienie silnie bakteriobójczego hydrochinonu) ${ }^{193}$. Zbyt duże dawki surowców arbutynowych bądź długotrwałe kuracje wyciągami z nich prowadzą do przewlekłego zatrucia objawiającego się anemią hemolityczną, stłuszczeniem wątroby, odbarwieniem włosów, złym samopoczuciem, wymiotami, biegunką itd.

\section{Związki garbnikowe}

Surowce roślinne oraz preparaty z nich mające działanie przeciwbiegunkowe mogą wywołać również szereg skutków ubocznych ${ }^{194}$. Długotrwałe stosowanie oraz zbyt duże dawki wyciągów zawierających związki garbnikowe (na przykład mocna herbata) wpływa na zahamowanie przyswajania wielu mikroelementów, m.in. selenu, miedzi,

\footnotetext{
190 Ibidem, s. 493.

191 Ibidem, s. 493-494.

192 Ibidem, s. 493-494.

193 Ibidem, s. 493-494.

194 Ziołolecznictwo. [W:] Encyklopedia zdrowia. T. 1, s. 494.
} 
oraz makroelementów, m.in. żelaza. Prowadzi to do utworzenia kompleksów z garbnikami nierozpuszczalnymi w wodzie; identyczne reakcje zachodzą z witaminami, m.in. witaminą $\mathrm{B}_{1}$ oraz niektórymi lekami zawierającymi alkaloidy ${ }^{195}$. Wskutek hydrolizy niektórych garbników, a szczególnie taniny, przez kwas żołądkowy, dochodzi do uwolnienia składników związków garbnikowych, m.in. kwasu galusowego, które mocno podrażniają błonę śluzową żołądka wywołując ból, nudności i wymioty. Kwas galusowy w niewielkim stężeniu jest silnym katalizatorem reakcji tworzenia się nitrozoamin $\mathrm{z}$ obecnych $\mathrm{w}$ przewodzie pokarmowym azotynów i amin. Należy podkreślić, iż to właśnie nitrozoaminy należą do najgroźniejszych związków rakotwórczych. Tanina uzyskiwana z galasów chińskich i tureckich oraz nalewka galasowa wykazuje podobne działanie do kwasu galusowego. Tanina w postaci środka ściągającego na oparzenia ulega częściowej hydrolizie oraz resorpcji i może spowodować nekrotyczne uszkodzenie wątroby.

\section{Związki saponinowe}

Saponiny w leczniczych dawkach powodują sekrecję śliny, podrażnienie błon śluzowych jamy ustnej, gardła i krtani, wzmożenie odruchów wykrztuśnych, natomiast nawet niewielkie przedawkowanie preparatów i leków zawierających związki saponinowe prowadzi do nadmiernego ślinienia, nudności oraz wymiotów. Zbyt duża dawka może prowadzić do uszkodzeń błony śluzowej przewodu pokarmowego i zatruć objawiających się zawrotami i bólami głowy, zaburzeniami akcji serca i krążenia, silnego bólu i nieżytu oskrzeli. Saponiny są truciznami hemolitycznymi in vitro ${ }^{196}$, na przykład mydlnica lekarska obfitująca w saponiny nie może być stosowana przy krwawieniach przewodu pokarmowego, stanach zapalnych żołądka, jelit, wątroby, po operacji jamy brzusznej i w przypadku biegunki.

\section{Inne związki toksyczne}

Należałoby też podkreślić, iż niektóre produkty spożywcze zawierają toksyczne związki chemiczne. Brokuły (kapusta szparagowa, Brassica oleracea L. var. italica Plenck), kapusta (Brassica L.) i kalafiory (Brassica oleracea L. var. botrytis L.) odznaczają się wysokim poziomem związków powodujących anomalie reprodukcyjne u szczurów. W orzeszkach ziemnych (Arachis hypogaea L.) i kukurydzy zwyczajnej (Zea mays) stwierdza się obecność toksyn grzybów. Popularna bazylia zawiera aż 50 związków o potencjalnym działaniu rakotwórczym, a w skład niektórych ziół wchodzą substancje działające silnie rakotwórczo. Substancje rakotwórcze ujawniono też w rzodkiewce zwyczajnej (Raphanus sativus L.), brązowej gorczycy (sarepskiej) (Brassica juncea), morelach (Prunus armeniaca L.), wiśniach (Prunus cerasus L.) i śliwkach (Prunus L.) ${ }^{197}$.

\footnotetext{
195 Ibidem, s. 494.

196 Ibidem, s. 495.

197 Zob. L.P. Graham. Chemia medyczna...
} 


\section{Podsumowanie}

Po krótkim przeanalizowaniu metod leczniczych wykorzystywanych od tysiącleci nasuwa się prosty wniosek: ludzie od zawsze interesowali się kwestiami zdrowotnymi. Szeregu istotnych odkryć dokonano już w starożytności, a nawet w czasach przedhistorycznych - zarówno intuicyjnie, jak drogą doświadczeń (prób i błędów), świadomie dążąc do uzyskania środka zwalczającego określoną chorobą, dolegliwość czy szczególnie dokuczliwe objawy choroby. Metody leczenia oraz profilaktyki chorób przy pomocy różnorodnych substancji (najczęściej, choć nie tylko, pochodzenia naturalnego) praktykowane przez przedstawicieli różnych kręgów cywilizacyjnych były w istocie bardzo zbliżone, choć nie były wolne od błędów. Na podkreślenie zasługuje fakt w pełni świadomego korzystania ze zdobytych przez poprzednie pokolenia doświadczeń, rozwój myśli naukowej i nieustanna chęć do doskonalenia środków i metod leczniczych, przynoszących korzyść zdrowiu ogółu społeczności. Wiele współcześnie stosowanych środków (fitoterapeutycznych, minerałowych, zwierzęcych, chemicznych) i zasad ochrony zdrowia opracowano przed kilkoma tysiącami lat, co starałam się przedstawić w powyższych rozważaniach. Na przypomnienie zasługuje również fakt, iż od początku lekarze traktowali organizm ludzki jako organiczną całość - some i psyche, co dziś w medycynie konwencjonalnej często niestety jest bagatelizowane. Wielki rozwój farmacji związany jest ściśle z rozwojem chemii - prowadzonymi doświadczeniami, które uwieńczone zostały szeregiem nowych odkryć, a przede wszystkim wyizolowaniem określonych substancji aktywnych, które zostały szybko wdrożone do lecznictwa. Przełom w medycynie stanowiło także odkrycie witamin, wpływających m.in. na zachowanie homeostazy w ustroju (ich niedobór powoduje liczne choroby i niedomagania). Wraz z postępem nauki wydłuża się przeżywalność.

\section{Bibliografia}

Aldride S. Magiczne cząsteczki. Jak działaja leki. Przeł. B. Paluchowska. Poznań: Dom Wydawniczy „Rebis”, 2001.

Baines J., Málek J. Wielkie kultury świata. Egipt. Przeł. z ang. T. Derda. Warszawa: Penta, 1995.

Barosiak M. Wąż Eskulapa, laska Asklepiosa i krew Gorgony. Cz. II. „Bez Recepty” 2001, nr 5.

Bartkowiak L. Kształtowanie się aptekarstwa w Polsce (XIII-XX wiek). Studium historiograficzne. Poznań: Wydawnictwo Naukowe Akademii Medycznej im. Karola Marcinkowskiego, 2004.

Bela Z. Etymologia i pierwotne znaczenia wyrazów lek i leczyć. „Gazeta Farmaceutyczna”, marzec 2011, s. 16-28. [Online:] <http://www.kwadryga.pl/upload/Dokumenty/Artykuly_naukowe/ GF_3_2011_naukowy.pdf> (dostęp: 25.08.2017).

Bergandy W. Od alchemii do chemii kwantowej. Zarys historii rozwoju chemii. Poznań: Wydawnictwo Naukowe UAM, 1997.

Blecharz-Klin K. et al. Interakcje leków roślinnych stosowanych $w$ chorobach układu oddechowego. „Herba Polonica” 2005, nr 3-4 (51), s. 89-97. [Online:] <http://www.iripz.pl/ftp/51_3_4_05_10. pdf> (dostęp: 11.06.2010).

Cavelius A., Frohn B. Zioła w medycynie naturalnej. Przeł. P. Montusiewicz. Bremen: Mak, 2005.

Czerny B. Uwagi na temat ubocznych efektów stosowania roślinnych środków leczniczych. „Postępy fitoterapii” 2000, nr 3, s. 21. [Online:] <http://www.czytelniamedyczna.pl/postepy_fitoterapii-67> (dostęp 11.06.2010). 
Czikow P., Łaptiew J. Rośliny lecznicze i bogate w witaminy. Z ros. przeł. H. Terpińska-Ostrowska. Wyd. 4. Warszawa: Państwowe Wydawnictwa Rolnicze i Leśne, 1988.

Danecki J. Co zawdzięczamy islamowi. [Online:] <http://www.opoka.org.pl/biblioteka/I/IR/co_islamowi.html> (dostęp: 12.02.2016).

Dłużewski S. Szen-Nung. Poczet wielkich fitoterapeutów. [Online:] <http://panacea.pl/articles. php?id=60> (dostęp: 16.05.2010).

Dobrogowski J. et al. Ból i jego leczenie. Seria Przewodnik Lekarza Praktyka. Warszawa: Springer PWN, 1996.

Encyklopedia zielarstwa i ziołolecznictwa. Red. H. Strzelecka, J. Kowalski. Warszawa: Wydawnictwo Naukowe PWN, 2000.

Farmakognozja. Podręcznik dla studentów farmacji. Red. I. Matławska, Poznań: Akademia Medyczna im. Karola Marcinkowskiego, 2005.

Farmakologia kliniczna. Red. A. Chodera, Z.S. Herman. Warszawa: Wydawnictwo Lekarskie PZWL, 2008.

Fitoterapia i leki roślinne. Red. E. Lamer-Zarawska et al. Warszawa: Wydawnictwo Lekarskie PZWL, 2007.

Giermaziak W. Poczatki farmacji w cieniu piramid. „Bez Recepty”, styczeń 2009.

Gorski P., Hanisz K., Jaroniewski W. Filozoficzne i przyrodnicze podstawy leku homeopatycznego w XIX w. Homeo sapiens. „Polski Kwartalnik Homeopatyczny” 1995, nr 1.

Graham L.P. Chemia medyczna. Podstawowe zagadnienia. Przeł. E. Mikiciuk-Olasik. Warszawa: Wydawnictwa Naukowo-Techniczne, 2003.

Graham L.P. Chemia leków. Przeł. Z. Zawadzki. Warszawa; Wydawnictwo Naukowee PWN, 2004.

Jaroniewski W., Jaroniewska D. Rośliny lecznicze i używki z Ameryki i Australii. Łódź: Instytut Wydawniczy Związków Zawodowych, 1996.

Hanisz K. Apteczki w polskich dworach i dworkach - historia farmacji. „Bez Recepty” 2001.

Hanisz K. Polihymnia u Asklepiosa. Cz. I: Historia farmacji. „Bez Recepty”, lipiec 2001.

Hanisz K. Polihymnia u Asklepiosa. Cz. II: Historia farmacji. „Bez Recepty”, październik 2001.

Hanisz K. Ziołolecznictwo w medycynie ludowej. Cz. I. „Bez Recepty” 2002, nr 9, s. 24-25.

Hanisz K. Ziołolecznictwo w medycynie ludowej. Cz. II: Fitoterapia magiczna. „Bez Recepty” 2002, nr 10, s. 24-25.

Hanisz K., Mularczyk J. Z historii leków uzależniających. Liście koka i kokaina. „Bez Recepty”, kwiecień 2002.

Hanisz K., Ewich M. Z dziejów reklamy aptekarskiej. „Bez Recepty” 2003, nr 10, s. 22-23.

Hanisz K., Z historii leków. Inhalacje, „Bez recepty” 2005, luty. [Online:] <http://bez-recepty.pgf.com. pl/index.php?co=artyk\&id_artyk=417> (dostęp: 12.05.2016).

Hilgier M. Historia i leczenie bólu przewlekłego. „Nowa Medycyna” 2001, z. 2 (110).

Historia leków naturalnych. T. 1: Źródła do dziejów etnofarmacji polskiej. Red. B. Kuźnicka. Warszawa: Wydawnictwo Instytutu Historii Nauki, Oświaty i Techniki, 1989.

Historia leków naturalnych. T. 2: Natura i kultura. Współzależności w dziejach lekoznawstwa. Red. B. Kuźnicka. Warszawa: Wydawnictwo Instytutu Historii Nauki, Oświaty i Techniki, 1989.

Historia leków naturalnych. T. 3: Ziołoznawstwo w dawnej i współczesnej kulturze Rzeszowszczyzny. Red. B. Kuźnicka. Warszawa: Wydawnictwo Instytutu Historii Nauki, Oświaty i Techniki, 1993.

Historia leków naturalnych. T. 4: Z historii i etymologii polskich nazw roślin leczniczych. Red. B. Kuźnicka. Warszawa: Wydawnictwo Instytutu Historii Nauki, Oświaty i Techniki, 1993.

Historia leków naturalnych. T. 5: Materia pharmaceutica. Red. B. Kuźnicka. Warszawa: Wydawnictwo Instytutu Historii Nauki, Oświaty i Techniki, 1999.

Historia leków naturalnych. T. 6: Rośliny odurzające polskiej literaturze naukowej XIX wieku. Red. B. Kuźnicka. Warszawa: Instytut Historii Nauki PAN, 2007. 
Historia medycyny. Wyd. 2 popr. i uzup. Red. T. Brzeziński. Warszawa: Wydawnictwo Lekarskie PZWL, 1995.

Jouanny J. Materia Medica. Leki homeopatyczne w praktyce medycznej. Wyd. 2 popr. i uzup. Lublin: Editions Boiron, Instytut Wydawniczy Daimonion, 1991.

Jütte R. Historia medycyny alternatywnej. Od magii do naturalnych metod leczenia. Tł. K. Jachimczak, E. Ptaszyńska-Sadowska. Warszawa: Wydawnictwo WAB. 2001.

Kardas P. Najstarsze leki. „Żyjmy dłużej” 1999, nr 12.

Kędzia B., Alkiewicz J. Interakcje pomiędzy lekami roślinnymi stosowanymi w inhalacjach a lekami syntetycznymi stosowanymi doustnie. „Postępy fitoterapii” 2006, nr 2, s. 105.

Knypl K. Miejsce aspiryny w codziennej praktyce lekarskiej. „Medycyna Rodzinna” 2003, nr 3-4.

Kora M. Zielona medycyna. Apiterapia, homeopatia, ziołolecznictwo. Przewodnik pacjenta. Wyd. 2 uzup. Warszawa: Oficyna Wydawnicza Eko-Vital, 1996.

Krzakowski M., Siedlecki P. Standardy leczenia systemowego nowotworów złośliwych u dorostych w Polsce. „Współczesna Onkologia” 2000, nr 4-5, s. 212-214, <http://www.termedia.pl/magazine.php?magazine_id=3\&article_id=691\&magazine_subpage=ABSTRACT $>($ dostęp: 1.07 .2010$)$.

Książkiewicz T. Zioła w walce z nowotworami. Uwierzyć wbrew nadziei. Warszawa: Oficyna Wydawnicza Rytm, 2000.

Kucharski S. Aptekarz zapatrzony w Stońce. „Bez Recepty”, czerwiec 2003.

Kucharski S. Coca-cole wynalazł aptekarz. „Bez Recepty”, maj 2003.

Kaniewski Ł. Lek $z$ kory trujacego drzewa. „Medycyna i Zdrowie” 21.03.2016. [Online:] <http:// www.rp.pl/Medycyna-i-zdrowie/303219873-Lek-z-kory-trujacego-drzewa.html\#ap-2> (dostęp: 8.02.2017).

Kuźnicka B. Znaczenie roślin halucynogennych w polskich tradycjach kulturowych. Zarys problematyki. „Analecta” 1992, nr 1, s. 111-122.

Majewski J. Pierwsze apteki w grodzie Lecha. „Bez Recepty”, styczeń 2003.

Majewski J. Muzea farmacji i zbiory aptekarskie w Polsce. Poznań: Wydawnictwo Kontekst, 2006.

Molenda J. Rośliny, które zmieniły świat; fakty i mity na temat właściwości leczniczych warzyw i owoców, anegdoty i zagadki roślinnych peregrynacji, kulisy ewolucji gatunków. Zakrzewo: Replika, 2011.

Nowy leksykon PWN. Warszawa: Wydawnictwo Naukowe PWN, 1998.

Onkologia. Podręcznik dla lekarzy i studentów. Red. R. Kordek. Gdańsk: ViaMedica, 2006.

Online Etymology Dictionary. [Online:] <https://www.etymonline.com/word/alchemy> (dostęp: 10.10.2017).

Paclitaxel-Ebewe (paklitaksel) - koncentrat do sporzadzania roztworu do infuzji. [W:] Baza leków. [Online:] <https://bazalekow.mp.pl/lek/63208,Paclitaxel-Ebewe-koncentrat-do-sporzadzaniaroztworu-do-infuzji> (dostęp: 2.08.2017).

Paluch A. Świat roślin w tradycyjnych praktykach leczniczych wsi polskiej. Wrocław: Wydawnictwo Uniwersytetu Wrocławskiego, 1984.

Palusiński R. Narkotyki. Przewodnik. Cz. 1: Soft - drugs: marijuana, LSD-25. Grzyby: historia, produkcja, sposób użycia, efekty, niebezpieczeństwa. Kraków: Total Trade \& Publishers, 1994.

Pluta J., Haznar-Garbacz D., Karolewicz B., Fast M. Preparaty galenowe. Wrocław: MedPharm Polska, 2010.

Royston A. Sto największych odkryć medycznych. Poznań: Podsiedlik-Raniowski i Spółka, 1995.

Rożnowska K. Witaminy i biopierwiastki. Kraków: Agencja Wydawniczo-Usługowa „Emilia”, 1997.

Russell S. Antybiotyki. Warszawa: Państwowe Wydawnictwo Naukowe, 1977.

Ryn J.Z. Medycyna indiańska. Kraków: Wydawnictwo Literackie, 2007.

Schott H. Kronika medycyny. Przeł. z niem. M. Dutkiewicz, B. Floriańczyk, A. Zaniewska. Warszawa: Horyzont, 2002. 
Seyda B. Dzieje medycyny w zarysie. Wyd. 3 uzup. Warszawa: Państwowe Zakłady Wydawnictw Lekarskich, 1977.

Skopińska-Różewska E., Strzelecka H., Nartowska J. Leki odpornościowe roślinne, <http://www.resmedica.pl/pl/archiwum/zdart20010.html> (dostęp: 3.07.2010).

Szczepański W. Leki pochodzenia zwierzęcego w farmakopeach polskich od 1560 do 1970. [W:] Historia leków naturalnych. Cz. 2: Natura i kultura - współzależności w dziejach lekoznawstwa. Red. B. Kuźnicka. Warszawa: Wydawnictwo Instytutu Historii Nauki, Oświaty i Techniki, 1989.

Szcześniak K. Świat roślin światem ludzi na pograniczu wschodniej i zachodniej Słowiańszczyzny. Gdańsk: Wydawnictwo Uniwersytetu Gdańskiego, 2008.

Szczygielska D. Kokainowiec pospolity. „Wiadomości Zielarskie” 1993, nr 7.

Szostak J. Farmakognozja, farmacja galenowa i aptekarstwo $w$ renesansowych zielnikach polskich. Warszawa: Wydawnictwo Lekarskie PZWL, 2006.

Szumowski W. Historia medycyny. Warszawa: PZWL, 1961 - Warszawa: Sanmedia, 1994.

Szumowski W. Historia medycyny filozoficznie ujęta. Seria Fundamenta - Antyk, t. 58. Kęty: Marek Derewiecki, 2008.

Świątek Ł. Nadzieja na nowe leki onkologiczne. „Aptekarz Polski” 2009,, nr 9 (31). [Online:] <http:// www.aptekarzpolski.pl/index.php?option=com_content\&task=view\&id=297\&Itemid=86> (dostęp: 1.07.2010).

The Oxford English Dictionary. Ed. J.A. Simpson and E.S.C. Weiner. Vol. 1, 2nd ed., Oxford: Clarendon Press - New York: Oxford University Press, 1989.

Thorwald J. Dawna medycyna, jej tajemnice i potega. Egipt, Babilonia, Indie, Chiny, Meksyk, Peru. Przeł. A. Bandurski i J. Sczaniecka Wrocław: Zakład Narodowy im. Ossolińskich - Wydawnictwo, 1990.

Trąbska-Świstelnicka M. Rozwój znieczulenia miejscowego w polskiej stomatologii. „Prace Historyczne" 2009, nr 4 (46).

Układ gniazdowy i słownik słów kluczowych wybranych kategorii kultury. Medycyna ludowa. Red. Cz. Robotycki, W. Babik. Kraków: Wydawnictwo Uniwersytetu Jagiellońskiego, 2005.

Wasilewski M. Minerał jako lek. Między starożytnością a współczesnością. Warszawa: Oficyna Wydawnicza Rytm, 2008.

Wasilewski B., Czelej J. Leksykon leków homeopatycznych. Warszawa: Split Trading, 1994.

Wielka encyklopedia powszechna PWN. T. 1-12. Warszawa: Państwowe Wydawnictwo Naukowe, 1960-1968.

Wolniak Z. Historia pierwszych aptek. „Bez Recepty”, lipiec 2003.

Wolniak Z. Korzenie aptek i zawodu lekarskiego. „Bez Recepty”, kwiecień 2009.

Wybrane zagadnienia z metod poszukiwania i otrzymywania środków leczniczych. Red. K. Kieć-Kononowicz. Wyd. 2 popr. Kraków: Wydawnictwo Uniwersytetu Jagiellońskiego, 2006.

Zawód farmaceuty na ziemiach polskich w XIX i XX wieku. Red. B. Urbanek. Katowice: Śląska Akademia Medyczna, Instytut Historii Nauki PAN, 2006.

Zielnik dla każdego, czyli opis ziół wykorzystywanych $w$ leczeniu domowym wraz z praktycznym zastosowaniem. Zebrał i oprac. J. Rogala oraz R. Maciej. Ożarów: Wydawnictwo Olesiejuk, 2009.

Ziołolecznictwo amazońskie i andyjskie. Red. K. Żurowska. Gdańsk: Tower Press, 2001. 